\title{
A Brief Overview of lncRNAs in Endothelial Dysfunction-Associated Diseases: From Discovery to Characterization
}

\author{
Rashidul Islam ${ }^{1}$ and Christopher Lai ${ }^{2, *(D)}$ \\ 1 Department of Health Technology and Informatics, Hong Kong Polytechnic University, Hong Kong, China; \\ rashidul.islam@studenti.unicam.it \\ 2 Health and Social Sciences Cluster, Singapore Institute of Technology, Singapore 138683, Singapore \\ * Correspondence: chris.lai@singaporetech.edu.sg; Tel.: +65-6592-1045
}

Received: 12 August 2019; Accepted: 7 September 2019; Published: 13 September 2019

\begin{abstract}
Long non-coding RNAs (lncRNAs) are a novel class of regulatory RNA molecules and they are involved in many biological processes and disease developments. Several unique features of lncRNAs have been identified, such as tissue-and/or cell-specific expression pattern, which suggest that they could be potential candidates for therapeutic and diagnostic applications. More recently, the scope of IncRNA studies has been extended to endothelial biology research. Many of lncRNAs were found to be critically involved in the regulation of endothelial function and its associated disease progression. An improved understanding of endothelial biology can thus facilitate the discovery of novel biomarkers and therapeutic targets for endothelial dysfunction-associated diseases, such as abnormal angiogenesis, hypertension, diabetes, and atherosclerosis. Nevertheless, the underlying mechanism of lncRNA remains undefined in previous published studies. Therefore, in this review, we aimed to discuss the current methodologies for discovering and investigating the functions of lncRNAs and, in particular, to address the functions of selected lncRNAs in endothelial dysfunction-associated diseases.
\end{abstract}

Keywords: endothelial dysfunction; lncRNAs; angiogenesis; hypertension; atherosclerosis; diabetes

\section{Introduction}

The endothelium, which is also known as the "tissue-blood barrier", is a monolayer of endothelial cells (ECs) that lines on the outer surface of blood vessels. This monolayer covers approximately $400 \mathrm{~m}^{2}$ throughout the entire blood circulation [1,2], and it was previously considered as merely a barrier with no specific function, but permeable to electrolytes and water [3]. Over time, the regulatory functions of the endothelium have gradually discovered. These include the control of vascular tone, cellular adhesion, blood fluidity, thrombosis, homeostasis, smooth muscle cell proliferation, angiogenesis, metabolism, and vascular permeability. They are facilitated by the synthetization and release of different important molecules, such as nitric oxide (NO), prostacyclin (PGI2), thromboxane (TXA2), bradykinin, endothelium derived hyperpolarizing factor (EDHF), endothelin-1 (ET-1), thromboxane A2, prostaglandin $\mathrm{H} 2$ (PGH2), and reactive oxygen species (ROS) [4-6]. The endothelium also actively maintains a precise balance in vasodilators, vasoconstrictors, and adhesion molecules for auto-regulation [7].

$\mathrm{NO}$ is considered to be the most potent endogenous vasodilator in our body. $\mathrm{NO}$ is synthesized from L-arginine metabolism by endothelial NO synthase (eNOS) [5] and then diffuses to vascular smooth muscle cells (VSMCs). The latter subsequently activates soluble guanylyl cyclase (sGC) and stimulates the production of cyclic guanosine $3^{\prime}, 5^{\prime}$-monophosphate (cGMP) from guanosine triphosphate (GTP). Finally, the intracellular $\mathrm{Ca}^{2+}$ concentration is decreased by cGMP through inhibiting phosphorylation pathways that enhances SMC relaxation and vascular tone [8]. 
The disruptions of the auto-regulatory processes in endothelium, including decreased production and bioavailability of NO, impaired endothelial dependent-NO-mediated vascular relaxation, upregulated inflammatory genes expression level, dysregulated hemodynamic, adhesion molecules up-expression, excessive ROS production, and enhanced vascular endothelium permeability [3-8]. They are conclusively referred as "endothelial dysfunction (ED)". Subsequently, the dysfunction leads to the development and progression of different forms of vascular diseases [6]. Numerous studies have discovered significant correlations between ED and vascular-mediated diseases, such as angiogenesis, atherosclerosis, hypertension, diabetes, insulin resistance, obesity, etc. [6]. However, the underlying pathophysiology of ED and the correlations between functional roles of IncRNAs and vascular-mediated diseases remain unclear. Therefore, we aim to provide a brief playbook for the discovery and characterization of lncRNAs in ED-associated diseases and, in particular, to provide a concise overview of current knowledge on lncRNAs in ED-associated diseases. It is believed that with a better understanding the correlations of lncRNAs and ED-associated diseases, researches can make a positive impact on the development of novel biomarkers and therapeutic targets in ED-associated disease treatments.

\section{IncRNAs in the Regulation of Gene Expression}

Advanced genome- and transcriptome-wide analyses discovered that $<2 \%$ of human genome contains protein coding transcripts, while $>75 \%$ of which were transcribed into noncoding RNAs (ncRNAs) and have no protein coding potentiality $[9,10]$. The ncRNAs can be broadly classified into two groups based upon their sizes: the short noncoding RNAs which are less than 200 nucleotides (nt) in length, such as small interfering RNAs (siRNAs), small nuclear RNAs (snRNAs), small nucleolar RNAs (snoRNAs), PIWI-interacting RNAs (piRNAs), and microRNAs (miRNAs), etc., and the lncRNAs, which are more than $200 \mathrm{nt}$ in size [11]. Both ncRNAs classes were found to be involved in many pathophysiological processes [12], but only the short ncRNAs, especially miRNAs, were extensively studied. miRNAs predominate the RNA biology research due to the higher sequence conservation across multiple species and better understanding of mechanism in every step of biological processes [13].

Over the last decades, lncRNAs have received much attention by researchers because of their gradually disclosed biological functions. Although they were found to be involved in a range of developmental processes and diseases, the underlying pathophysiological mechanisms remain limited. Despite there being controversial findings that were reported in previous lncRNAs studies [14-16], the functions of many lncRNAs are largely unclear. Those findings on lncRNAs have indeed provided important evidence regarding their roles in the biological regulation.

Similar to mRNA, the mechanisms of biogenesis of IncRNAs are also gradually uncovered. Nowadays, most of the lncRNAs are usually transcribed by RNA polymerase-II (pol II), and then capped at $5^{\prime}$-end, spliced and polyadenylated at $3^{\prime}$-end [17]. IncRNAs are distributed throughout the genome. Based on their genomic locations and characteristics, they can be categorized into five types: sense, antisense, bidirectional, intronic, or intergenic. The details on genomic locations of lncRNAs refer to Laurent et al. 2015 [18]. More importantly, as far as molecular functions of lncRNAs are of concerned, numerous studies revealed that their cellular localization is the primary determinant of their functions [19-21]. A number of studies were conducted by Batista and Chang, 2013, Mercer et al. 2008 and others to detect the subcellular localizations of lncRNAs [20,21]. In addition, the traits of lncRNAs, presented in nucleus and/or cytoplasm. Interestingly, the cytoplasmic lncRNAs are mainly involved in the regulation of translation or signal transduction process. On the other hand, the nuclear lncRNAs are mainly implicated in the regulation of gene transcription process [21,22]. As mentioned earlier, thousands of lncRNAs were found to be involved in various pathophysiological processes, including ED and its associated diseases. Unfortunately, only a few identified lncRNAs were functionally characterized by previous published studies $[12,13,23,24]$.

IncRNAs can regulate gene expression at both the transcriptional and post-transcriptional levels through diverse mechanisms $[25,26]$. In most cases, IncRNAs can regulate the transcription process 
via chromatin modulation [23]. IncRNAs can also bind single or multiple chromatin modifying complexes and target their activities to particular DNA loci. For example, HOX transcript antisense RNA (HOTAIR) was found to be directly associated with Lys-specific demethylase 1 (LSD1), Polycomb repressive complex (PRC2), of which are responsible for removing the active demethylation of lysine 4 residue on histone 3 (H3K4me2) [24]. Another lncRNA antisense transcript of GATA6 (GATA-AS) was found to regulate endothelial gene expression through interacting with epigenetic regulator lysyl oxidase-like 2 (LOX2) to remove activated trimethylation of lysine 4 of histone H3 (H3K4me3) [27].

On the other hand, IncRNAs-mediated chromatin modulations can either activate or repress gene expression, depending on the nature of the enzyme or factors to be bound during remodeling [23,28,29]. Furthermore, it is also revealed that the carboxyl-teminal domain (CTD) of Pol II can bind with chromatin modifying complexes and alter lncRNAs transcription $[23,30]$. In human umbilical vein endothelial cells (HUVECs), MANTIS has been found to act as a scaffolding lncRNA within a chromatin remodeling complex and up-regulate endothelial genes, including SRY (Sex Determining Region Y)-Box 18 (SOX18), mothers against decapentaplegic homologue 6 (SMAD6), and chicken ovalbumin upstream promoter transcription-factor-2 (COUP-TFII) transcription by enabling pol II binding to the transcription stat sites (TSS) [31]. However, IncRNAs transcription can cause chromatin remodeling and it leads to either stimulating or inhibiting the binding of regulatory factors [32,33], and even directly influence the transcription process. For example, several lncRNAs synthesized from arthrobacter luteus (Alu) short interspersed elements (SINE) elements and directly bound with pol II can repress the transcription of specific mRNA during heat shock [34]. Furthermore, the assembly of pre-initiation complex in trans can be inhibited by highly up-regulated lncRNAs through the formation of a DNA-RNA triplex structure [35]. Importantly, lncRNAs can fold into structures that stimulate or inhibit the activity of different transcription factors and mimic DNA-binding sites [23]. For example, growth arrest specific 5 (GAS5) represses glucocorticoid receptor (GR)-mediated transcription by folding into a particular shape that mimics the DNA-binding site of the GR [36]. Besides, lncRNAs can also regulate gene expression through binding particular transcriptional factors to inhibit the nuclear localization of specific transcription factors [37]. For instance, the non-coding repressor of NFAT (NRON) obstructs nucleocytoplasmic shuttling of the transcription factor nuclear factor of activated T-cells (NFAT) and indirectly represses the transcription process [37]. A recent study has described an atlas of transcriptional regulating lncRNAs in HUVECs under hypoxic condition, which suggests the potential of lncRNAs as a future development biomarker of endothelial hypoxia in atherosclerosis lesion and/or other vascular diseases [38].

Besides, lncRNAs are also critically involved in the mRNA processing and post-transcriptional regulation by serving as promising source of miRNA, negative regulator of miRNA and stimulator of miRNA-independent mRNA degradation [30]. In addition, antisense lncRNAs can also directly modulate mRNA expression via a close association of the duplex with adenosine deaminase acting on RNA (ADAR) enzymes in double-stranded RNA [39]. Furthermore, lncRNAs are also contributed in the post-transcriptional events and protein synthesis. For example, IncRNA containing SINEB2 repeat elements were associated with $5^{\prime}$ region of mRNA to upregulate the translational process [40]. Likewise, lncRNAs are implicated in regulating mRNA stability, e.g., BACE1 (beta-secretase 1)-antisense RNA (BACE1AS) increases BACE1 mRNA stability through the abrogation of miRNA-induce repression [41]. In contrast, lncRNAs can mask the miRNA-binding sites on a specific target mRNA in order to block miRNA-induced silencing by generating the RNA-induce silencing complex [42]. In addition, linear or circular lncRNAs can function as miRNA decoys to sequester miRNAs from their target mRNAs [43].

There are several types of lncRNAs that have been characterized as a post-transcriptional regulator of endothelial genes. For example, antisense mRNA (sONE) was found to mediate the post-transcriptional down-regulation of eNOS during hypoxia. It plays a critical role in the etiology of vascular diseases, including pulmonary arterial hypertension [44,45]. In summary, lncRNAs might directly influence the expression level of endothelial genes at the transcription 
and/or post-transcriptional level, leading to impaired endothelium function in both physiological and pathological conditions.

\section{Functional Roles of IncRNAs in Endothelial Dysfunction}

Impaired endothelial function is linked with the initiation and progression of various diseases, including abnormal angiogenesis, atherosclerosis, hypertension, and diabetes. ED can be triggered by different biochemical and biomechanical stimuli, such as modified low-density lipoprotein (LDL), Interleukin 1 beta (IL-1 $\beta$ ), disturbed blood flow, etc., of which have been considered as the primitive step to induce atherosclerotic lesion [46]. Similarly, the synthetization and expression of adhesion molecules and chemokines, such as vascular cell adhesion molecule-1 (VCAM-1), E-selectin, monocyte chemoattractant protein-1 (MCP-1), and C-X3-C motif chemokine ligand 1 (CX3CL1), can accelerate leukocyte adhesion. It subsets onto the vessel wall and compromises the endothelial integrity, leading to the initiation of vascular inflammation and atherosclerosis [47,48]. Although the regulatory mechanisms of ED and its associated diseases have been identified, their underlying mechanisms are under further investigation for improving the diagnostic and treatment accuracy.

Numerous $\operatorname{lncRNAs}$ are functionally correlated with ED and its associated diseases in recent studies, such as highly upregulated in liver cancer (HULC) [49,50], metastasis associated lung adenocarcinoma transcript 1 (MALAT1) [51-60], maternally expressed 3 (MEG3) [61-68], taurine up-regulated 1 (TUG1) [69-71], plasmacytoma variant translocation 1 (PVT1) [72,73], ANRIL (CDKN2B-AS1) [74,75], HOTAIR [76,77], retinal non-coding RNA3 (RNCR3) [78,79], X-inactive specific transcript (XIST) [80], and H19 imprinted maternally expressed transcript (H19) [81]. Moreover, lncRNAs can interact with different functional molecules and alter the indispensable steps of ED, including NO production, vascular tone regulation, endothelium activation/deactivation, inflammatory response, barrier function, EC proliferation, migration, and apoptosis [82]. For example, one of the most widely studied lncRNAs, MALAT1, was involved in the regulation of EC proliferation, apoptosis through inhibiting cell cycle progression, and modulation in the expression level of vascular endothelial growth factor (VEGF) $[55,56,59]$. Additionally, the knockdown of MALAT1 can reduce the S-phase cyclins named cyclin A2 (CCNA2), cyclin B1 (CCNB1), and cyclin B2 (CCNB2) in ECs [59], decrease the expression level of phosphorylated $\mathrm{P}^{38}$ in retinal ECs [55], and reduce the activation of phosphatidylinositol 3-kinase (PI3K) and AKT serine/threonine kinase 1 (Akt) phosphorylation in human brain vascular endothelial cells (VECs) [60]. It further increases the expression level of cell cycle inhibitory genes $\mathrm{P}^{21}, \mathrm{P}^{27 \mathrm{Kip} 1}$, interleukin 6 (IL-6), and tumor necrosis factor $\alpha(\mathrm{TNF} \alpha)$ in HUVECs, leading to subsequent decreased cell proliferation and increased cell apoptosis [56,60]. Besides, overexpressed MALAT1 promotes EC proliferation and inhibits cell apoptosis [60]. Moreover, the pharmacological inhibition of MALAT1 expression in vivo could reduce blood vessel capillary density and blood flow recovery, which suggests its involvement in EC proliferation and vascular outgrowth in in vitro condition [59]. Its interactions with different miRNAs (miR-22-3p, miR-320a, miR-26b) and modulate EC homeostasis, proliferation, apoptosis, autophagy, angiogenesis, and vascular inflammation were further revealed [58,83,84].

On the other hand, another widely studied lncRNA, MEG3, was found to be downregulated in EC. The knockdown of MEG3 could increase EC proliferation, migration, and angiogenesis through regulating the PI3K/Akt singling pathway $[63,67]$. Similar to MALAT1, MEG3 can also interact with miR-9 and modulate EC proliferation and angiogenesis [63]. Taking altogether, it can be postulated that lncRNAs play a significant role in development and progression of ED and its associated diseases. Figure 1 presents a summary of the known functional correlations between lncRNAs, ED and ED associated diseases such as irregular angiogenesis, vascular diseases, hypertension, diabetes, and atherosclerosis. 


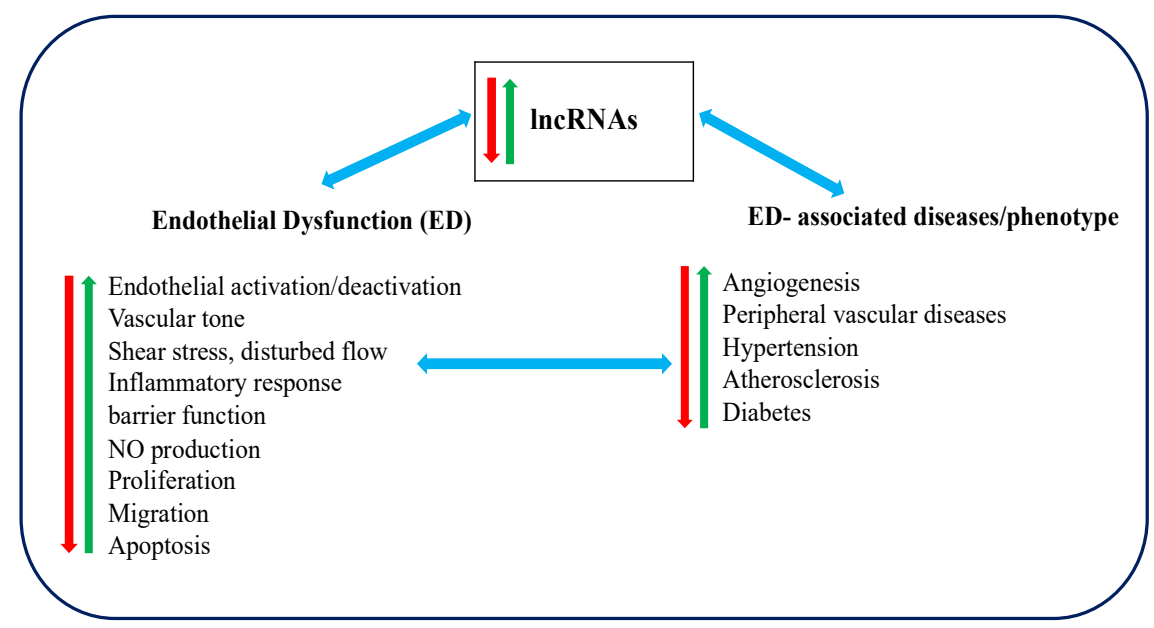

Figure 1. A summary of the functional correlations between Long non-coding RNAs (lncRNAs), Endothelial dysfunction (ED) and ED-associated diseases (red arrows represent downregulation or inhibition, green arrows represent upregulation and blue arrows represent possessing causal relationship).

\section{Methods for Studying lncRNA: From Discovery to Function}

Unlike mRNA, the expression levels of lncRNAs genes are relatively lower and rather cell-and/or-tissue-specific. Additionally, the sequence of lncRNA does not provide much information about their functional information, making the discovery and characterization of lncRNA very challenging $[85,86]$. In this chapter, we attempted to briefly summarize the current available methodologies (Figure 2) for the discovery and characterization of cellular functions of lncRNAs.

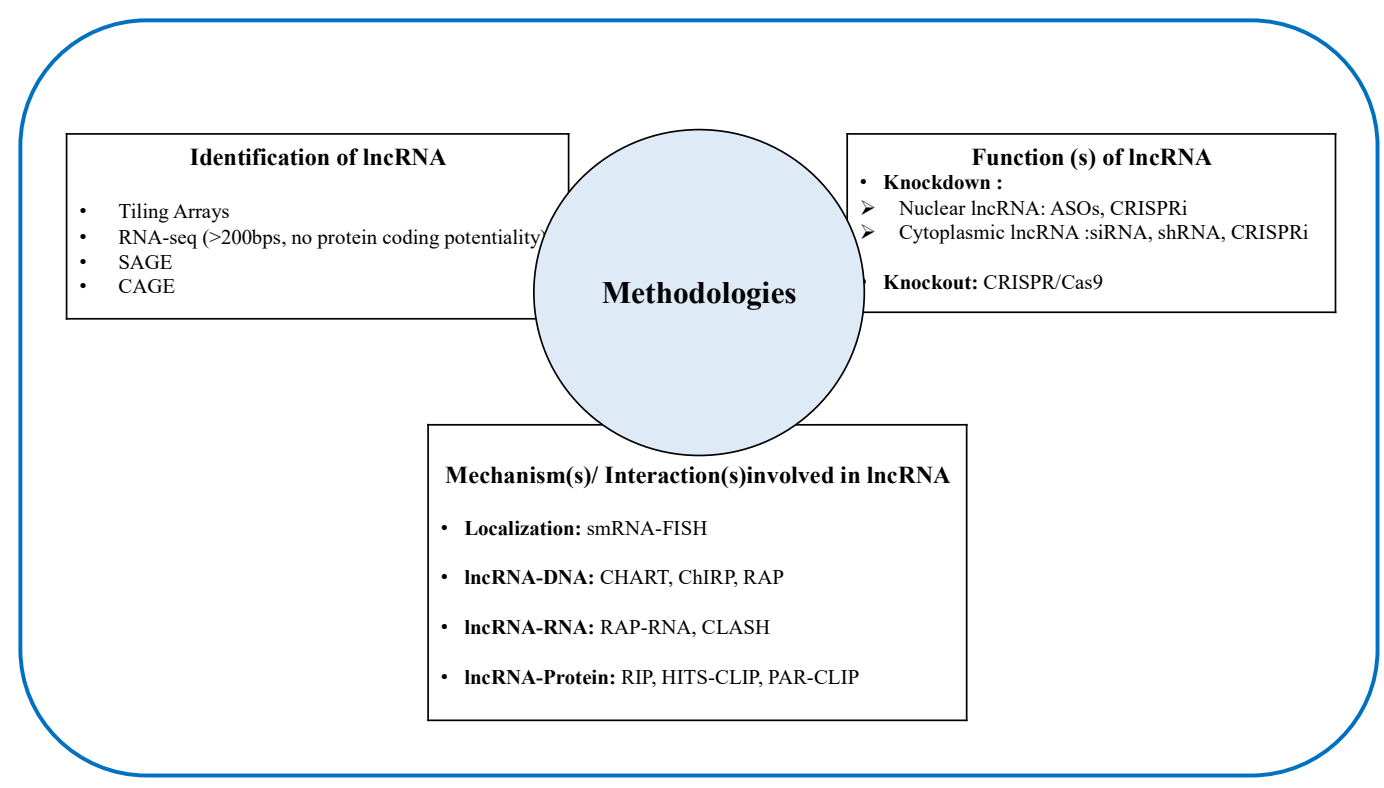

Figure 2. A summary of the current available methodologies for the discovery and characterization of the cellular functions of lncRNAs. RNA-seq: RNA sequencing; SAGE: Serial analysis of gene expression; CAGE: Cap analysis of gene expression; ASOs: Antisense oligonucleotides; CRISPRi: CRISPR interference; siRNA: Small interfering RNA; shRNA: Short hairpin RNA; smRNA: Single-molecule RNA; FISH: Fluorescence in situ hybridization; CHART: Capture hybridization analysis of RNA target; ChIRP: Chromatin isolation by RNA purification; RAP: RNA antisense purification; CLASH: Cross-linking, ligation and sequencing of hybrid; RIP: RNA immunoprecipitation; HITS-CLIP: High-throughput sequencing of RNA isolated by cross-linking immunoprecipitatio; PAR-CLIP: Photoactivatable ribonucleotide-enhanced cross linking and immunoprecipitation. 


\subsection{Methods to Identify/Discover $\operatorname{lnc} R N A s$}

A lncRNA study usually begins with the identification process. As mentioned earlier, lncRNAs are tissue specific and they have a lower expression level than coding genes, therefore it is always very critical and challenging to select the most appropriate method in the identification process [87]. Currently, there are several advanced techniques that are available to identify lncRNAs (Table 1), and these advanced techniques will be briefly described in the following paragraphs:

Table 1. An overview of the commonly used methodologies to identify lncRNAs and the advantages and disadvantages over its use. SAGE: Serial analysis of gene expression; CAGE: Cap analysis of gene expression; RNA-seq: RNA sequencing

\begin{tabular}{|c|c|c|c|}
\hline Method & Advantages & Disadvantages & References \\
\hline Tiling arrays & $\begin{array}{l}\text { Able to identify and quantify the } \\
\text { expression level of transcripts (up to } \\
\text { few hundred fold) }\end{array}$ & $\begin{array}{l}\text { - Limited to distinguish different } \\
\text { isoforms and allelic expression } \\
\text { Higher background noise and } \\
\text { cost effective }\end{array}$ & {$[86,88,89]$} \\
\hline SAGE & $\begin{array}{ll}\text { - } & \text { Allows novel } \\
\text { transcripts identification } \\
\text { - } \quad \text { Capable to distinguish different } \\
\text { isoforms and allelic expression }\end{array}$ & $\begin{array}{l}\text { - } \quad \text { Relatively low-throughput } \\
\text { - High cost effective }\end{array}$ & {$[90,91]$} \\
\hline CAGE & $\begin{array}{l}\text { - Can identify promoter region } \\
\text { and TSS }\end{array}$ & $\begin{array}{l}\text { - } \quad \text { Limited to the } 5^{\prime} \text {-capped transcripts } \\
\text { - } \quad \text { High cost effective }\end{array}$ & [92-96] \\
\hline RNA-Seq & $\begin{array}{l}\text { Able to identify and quantify the } \\
\text { expression level of transcripts } \\
\text { (>8000 fold) } \\
\text { Allows to distinguish different } \\
\text { isoforms and allelic expression } \\
\text { - Lower background noise }\end{array}$ & $\begin{array}{l}\text { - Time consuming method } \\
\text { - Complex bioinformatics (data } \\
\text { analysis) issues }\end{array}$ & [97-99] \\
\hline
\end{tabular}

\subsubsection{Tiling Arrays}

Tiling arrays contain high-density oligonucleotide probes that can encompass non-repetitive sequence of specific chromosome and whole genome analysis $[88,89]$. The advantage of using tiling arrays over the conventional microarray method is that the former allows alternative splicing analysis, polymorphism detection and identification of novel transcripts $[86,88,89]$. For example, HOTAIR was identified from the human HOX gene cluster by using high resolution tiling array that was designed with 400 thousands of overlapping probes [100]. Although tiling arrays have been considered as the gold standard method for detecting and quantifying the expression analysis of transcripts, it is now largely replaced by next generation sequencing (NGS) technologies, owing to its higher background noise and higher cost $[86,101]$.

\subsubsection{Serial Analysis of Gene Expression (SAGE)}

SAGE is one of the first genome-wide gene expression analyzing methods that allows for comprehensive, unbiased, and quantitative analysis of gene expression profiles without prior knowledge of gene of interest [90,91]. For example, a systemized 272 human SAGE experiments were performed to identify and analyze the expression profile of lncRNAs in both normal and cancerous tissues [102].

\subsubsection{Cap Analysis of Gene Expression (CAGE)}

CAGE is a high-throughput NGS based method that allows for the identification and quantification of the expression of 5'-capped RNAs [92-95]. In contrast, SAGE can only cover the $3^{\prime}$-end of RNAs and it is unable to provide any information about $5^{\prime}$-end regulatory elements [103]. A total of 19,175 lncRNAs were functionally identified and profiled through integrating various CAGE-seq data analysis [104]. 
Despite having the aforementioned advantages over SAGE and hybridization based methods, CAGE itself is limited by the $5^{\prime}$-capped transcripts and it is unable to cover circular RNAs together with non-caped RNAs [93,105].

\subsubsection{RNA Sequencing (RNA-Seq)}

RNA-seq has competence in detecting sequence variations, alternative splicing isoforms, gene fusion events, and novel splice junctions over using hybridization or sanger sequencing based methods e.g., Tiling arrays, SAGE, and CAGE etc. [97,98,106,107]. In RNA-seq, non-polyadenylated ((poly(A)-) RNAs are first depleted and poly(A)+ RNAs are converted into the cDNA fragments library. Subsequently, sequencing adaptors are introduced into each cDNA fragment and short sequencing is acquired by any high-throughput sequencing technologies $[97,108,109]$. Finally, sequencing reads align with the reference genome and that will provide genome-wide transcription mapping. The library preparation and final bioinformatics analysis are the major challenges and drawbacks of RNA-seq despite having numerous advantages.

\subsection{Methods to Study the Functional Roles of IncRNAs}

Following the identification step, the second challenge in both in vitro and in vivo studies is to investigate whether the newly identified lncRNAs are involved in any biological role or not. Nowadays, there are several methods to unveil the functions of lncRNAs and to classify lncRNAs into different biological phenotypes [110,111]. Table 2 summarizes a brief overview with a comparison of the advantages and disadvantages of the widely used methods for investigating lncRNAs cellular functions under different physiological and/or pathological conditions.

Table 2. The advantages and disadvantages of different widely used methods to investigate the cellular functions of lncRNAs in different physiological and/or pathological conditions. RNAi: RNA interference; siRNA: Small interfering RNA; shRNA: Short hairpin RNA; ASOs: Antisense oligonucleotides; sgRNA: Single guide RNA; CRISPRi: CRISPR interference; dCas9: nuclease-dead deactivated Cas9.

\begin{tabular}{|c|c|c|c|}
\hline Method & Advantages & Disadvantages & References \\
\hline RNAi & $\begin{array}{l}\text { - } \quad \text { High knockdown efficiency } \\
\text { - } \quad \text { shRNAs allow inducible and sable } \\
\text { silencing for long-term } \\
\text { - } \quad \text { Relatively fast and easy to use } \\
\text { - } \quad \text { Cost effective }\end{array}$ & $\begin{array}{l}\text { - Inducible and sable long-term } \\
\text { silencing is not possible with siRNAs } \\
\text { Knockdown variability } \\
\text { and incompleteness } \\
\text { - } \quad \text { Off-target effect of siRNA }\end{array}$ & [112-115] \\
\hline ASOs & $\begin{array}{l}\text { - } \\
\text { - } \quad \text { Easy to to knockdown nuclear lncRNA } \\
\text { increase efficiency }\end{array}$ & $\begin{array}{l}\text { - } \quad \text { Less effective to cytoplasmic lncRNA } \\
\text { - } \quad \text { Higher off-target effect }\end{array}$ & [116-119] \\
\hline CRISPR/Cas9 & $\begin{array}{l}\text { - } \begin{array}{l}\text { Highly specific and negligible } \\
\text { off-target effect }\end{array} \\
\text { - } \quad \text { High recombination frequency } \\
\text { - } \quad \text { Multiple sgRNA can be used to } \\
\text { achieve complete } \\
\text { lncRNA perturbation }\end{array}$ & $\begin{array}{l}\text { - Interaction with neighboring genes } \\
\text { - } \quad \text { Provides false positive effect }\end{array}$ & [120-124] \\
\hline CRISPRi & $\begin{array}{l}\text { Provides robust gene suppression } \\
\text { and activation } \\
\text { - } \quad \begin{array}{l}\text { Effective in both nucleus and } \\
\text { cytoplasmic lncRNA }\end{array} \\
\text { - } \quad \begin{array}{l}\text { Highly specific with minimal } \\
\text { off-target effect }\end{array}\end{array}$ & $\begin{array}{l}\text { - dCas9 can repress downstream } \\
\text { genes within an operon instead of an } \\
\text { individual gene } \\
\text { - Multiple components need to } \\
\text { transfect into the cell }\end{array}$ & {$[125,126]$} \\
\hline
\end{tabular}

\subsubsection{RNA Interference (RNAi)}

RNAi is the most extensively used method for achieving "loss-of-function study" through the knockdown of lncRNAs [111-113,127]. RNAi methods, such as small interfering RNA (siRNA) and short hairpin RNA (shRNA), usually use 20-40 nucleotide transcripts which are complimentary to the target transcript and make duplexes that are subsequently degraded by the cellular machinery [112]. 
siRNAs target the transcript of interest in a transient fashion, while shRNAs are stably expressed [113]. It is still controversial that RNAi methods can only target cytoplasmic lncRNAs but not nuclear IncRNAs $[19,128]$. Nevertheless, recently, the RNAi method has been effectively used to target some nuclear lncRNAs $[113,129]$. It has been suggested that the complex structured nature and the lower expression level of lncRNAs can hinder the accuracy of RNAi methods. Therefore, further modification procedures are needed to address these limitations [87,115].

\subsubsection{Antisense Oligonucleotides (ASOs)}

ASOs are synthetic single stranded nucleic acid derivatives, forming RNA-DNA hybrids and inducing the cellular RNAs degradation by endogenous RNase H [116-118,130]. The knockdown efficiency of both RNAi and ASOs critically depends on the subcellular localization of lncRNAs. For example, the RNAi methods effectively suppress cytoplasmic lncRNAs, but nuclear lncRNAs are more efficiently suppressed by ASOs [119]. Therefore, it has been recommended that the RNAi and ASOs can be used together to target dual-localize (present in both nucleus and cytoplasm) lncRNAs [119]. Today, ASOs based method is considered as a promising tool for investigating lncRNAs functionality, especially for novel lncRNAs.

\subsubsection{CRISPR/Cas System}

The CRISPR/Cas system is the most advanced, robust, and highly efficient gene manipulating method for revealing the biological functions of lncRNAs, both in vitro and in vivo $[120,131]$. There are different manners of the CRISPR/Cas system that can be applied to induce a partial or complete deletion of the lncRNAs genomic locus [120,132], insert polyadenylated signals and make an interruption between the promoter and lncRNA sequence [133], target a transcriptional activator complex to the promoter [134], and insert a robust promoter upstream of the gene to overexpress lncRNA in order to accomplish successful "gain or loss-of-function" studies of lncRNAs [135]. The knockout of lncRNA study was initiated while using a pair of single guide RNA (sgRNA) that targeted two specific locations flanking the selected lncRNA gene and permanently eradicate the entire genomic locus [122]. Alternatively, lncRNA transcription can also be abolished by depleting the main promoter region of lncRNA of interest. It gives higher knockout efficiency than conventionally deleting whole genomic locus $[120,123]$. However, if lncRNA contains multiple promoters in their sequence, then these promoters needed to be examined to find the best knockout effect on the expression of lncRNA. Moreover, the CRISPR/Cas9 system was further utilized to improve the silencing efficiency of lncRNAs through inserting a PolyA-transcriptional terminator $[124,136]$. A biallelic PolyA signal can also be inserted into different sites using this method, such as at the site immediately after the promoter, at the first exon, or at the first intron of the targeted gene through CRISPR/Cas9 mediated homology direct repair (HDR) system to enhance the silencing efficiency $[121,124,136]$. However, the target gene transcription cannot be entirely blocked by this method. Therefore, this method would be the best choice for the functional study of the lncRNA genes, whose deletions or complete knockout could induce lethal phenotype.

\subsubsection{CRISPR Interference (CRISPRi)}

CRISPRi can efficiently silence any gene transcription by sgRNA facilitated targeted recruitment of the nuclease-dead deactivated Cas9 (dCas9)-Kruppel-associated box (KRAB) repressor domain to the TSS [125,126,137-140]. CRISPRi can be applied to target any lncRNA gene, owing to its capacity to act in a range of $1 \mathrm{~kb}$ around the TSS and block $23 \mathrm{bp}$ of targeted sequence [139,141]. With the application to chromatin modification nearby the TSS and transcriptional road-blocking ability, CRISPRi also expended to unveil the potential functions of lncRNAs. For example, the roles of lncRNAs in the production of cis-and-trans-acting RNA transcript [29], enhancer like function, cis-mediated regulation of gene function while using the CRISPRi method were published [29,142-144]. The CRISPRi allows for the repression of a targeted locus without whole genome editing, and characterized by highly 
efficient without no-to-little off-target effects due to false dCas9 binding or accidental silencing of other nearby regulatory elements [122,126]. However, the effectiveness of using CRISPRi methods for lncRNA study is limited by the prerequisite knowledge regarding the location of the promoter or enhancer. In addition, re-confirmation of the observed specific regulatory elements solely regulates the transcription of selected lncRNA.

\subsection{Different Methods to Unveil the Functional Mechanisms of IncRNAs}

Prediction of lncRNAs functions is arduous, because their sequence does not provide much information regarding their function alike mRNA. It is generally accepted that the localization of lncRNAs within the cell is the primary determinant of their molecular functions [19]. Broadly, there are two approaches, named "absolute approach" and "relative approach", that are commonly used to detect RNA localization [145]. The absolute localization refers to the ratio of molecules or mass of RNA between two compartments. There are several quantification methods, such as Image analysis ((e.g., fluorescence in situ hybridization (FISH), Single-cell RNA FISH, multiplexed error-robust fluorescence in situ hybridization (MERFISH)), Microarray (e.g., Fractionation), are commonly used to detect the absolute localization of lncRNA $[145,146]$. On the other hand, the relative method merely calculates the ratio of concentrations in the two compartments while using several sequencing based methods, such as RNA-seq (e.g., Fractionation, APEX-RIP, APEX-seq, etc.) [145]. Yet, most of the global subcellular RNA maps are based on relative localization.

Absolute and relative methods can both efficiently detect specific lncRNA localization in different organelles, including nucleus, nucleolus, nuclear lamina, nuclear pore, nucleoplasm, cytoplasm, cytoplasmic membrane, insoluble cytoplasmic fraction, chromatin, cytosol, mono-and polysomes, mitochondria, mitochondrial matrix, outer mitochondrial membrane, endoplasmic reticulum (ER), ER membrane, ER lumen etc. [145]. For the sake of easy understanding, all of these organelles are considered under nucleus and cytoplasm. So, it is usually described that lncRNAs are present in the nucleus or/and cytoplasm, which help to predict their (lncRNAs) possible functions. For example, cytoplasmic lncRNAs mainly regulate mRNA stability or translation and influence cellular signaling cascades, while nuclear lncRNAs are critically involved in the chromatin interaction, transcriptional regulation, and RNA processing $[147,148]$. For details on genomic location of lncRNAs refer to Carlevaro-Fita J, Johnson R. [145].

Following the successful identification of subcellular localization of lncRNA, the interactions between IncRNAs and other regulatory macromolecules, including DNA, RNA, and protein in different biological processes can be investigated while using the different advanced methods that are summarized in Table 3. In the following chapter, we will briefly describe the most advanced and widely used methods for detecting the subcellular localization of lncRNAs and their molecular interactions with DNA, RNA, and protein.

Table 3. Advantages and disadvantages of commonly available methods to identify the subcellular localization and potential interaction of lncRNAs with DNA, RNA, and protein. smRNA-FISH: single-molecule RNA fluorescence in situ hybridization; CHART: Capture hybridization analysis of RNA target; ChIRP: Chromatin isolation by RNA purification; RAP: RNA antisense purification; RAP-RNA: RNA antisense purification followed by RNA sequencing; CLASH: Cross-linking, ligation and sequencing of hybrids; RIP: RNA immunoprecipitation; HITS-CLIP: High-throughput sequencing of RNA isolated by cross-linking immunoprecipitation; PAR-CLIP: Photoactivatable ribonucleotide-enhanced cross linking and immunoprecipitation.

\begin{tabular}{lllll}
\hline Purpose of Study & Method & \multicolumn{1}{c}{ Advantages } & Disadvantages \\
\hline $\begin{array}{c}\text { Identification of } \\
\text { subcellular } \\
\text { localization }\end{array}$ & smRNA-FISH & $\begin{array}{l}\text { Detect the subcellular } \\
\text { localization of low- } \\
\text { abundance lncRNA } \\
\text { Quantify the absolute level } \\
\text { of lncRNA }\end{array}$ & $\begin{array}{l}\text { Possibility to detect false } \\
\text { positive result }\end{array}$ \\
\hline
\end{tabular}


Table 3. Cont.

\begin{tabular}{|c|c|c|c|c|}
\hline Purpose of Study & Method & Advantages & Disadvantages & References \\
\hline \multirow{3}{*}{$\begin{array}{l}\text { Investigation of } \\
\text { lncRNA-DNA } \\
\text { interaction }\end{array}$} & CHART & $\begin{array}{l}\text { - } \quad \text { No prior knowledge is required } \\
\text { Reduced background signal due } \\
\text { to fewer probes used }\end{array}$ & $\begin{array}{l}\text { - Cross linking agent } \\
\text { formaldehyde is not } \\
\text { efficient enough } \\
\text { - Time consuming method }\end{array}$ & {$[86,151,152]$} \\
\hline & ChIRP & $\begin{array}{l}\text { - } \quad \text { Able to detect genome-wide } \\
\text { lncRNA-DNA binding sites } \\
\text { - } \quad \text { Less off-target effect }\end{array}$ & $\begin{array}{l}\text { Incapable to disclose } \\
\text { individual lncRNA } \\
\text { domain function } \\
\text { Higher } \\
\text { noise-to-signal ratio }\end{array}$ & [153-155] \\
\hline & RAP & $\begin{array}{l}\text { - } \quad \text { Able to detect residual } \\
\text { lncRNA fragments } \\
\text { Provides higher binding affinity } \\
\text { to target lncRNA due to larger } \\
\text { RNA probe used } \\
\text { - } \quad \text { Reduced signal-to-noise ratio }\end{array}$ & 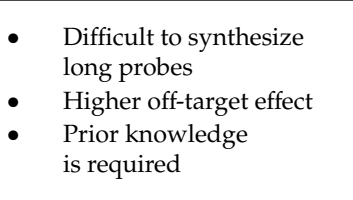 & {$[156,157]$} \\
\hline $\begin{array}{l}\text { Investigation of } \\
\text { lncRNA-RNA } \\
\text { interaction }\end{array}$ & CLASH & $\begin{array}{ll}\text { - } & \text { Capable to map RNA-RNA } \\
\text { interactions in vivo } \\
\text { - } \\
\text { Provides RNA-RNA binding } \\
\text { sites \& level resolution }\end{array}$ & $\begin{array}{ll}\text { - } & \text { Relatively low efficiency } \\
\text { - } & \text { Low ligation rate } \\
\text { between short } \\
\text { RNA fragments } \\
\text { - } \quad \text { Bait protein information } \\
\text { is required }\end{array}$ & [159-162] \\
\hline \multirow{2}{*}{$\begin{array}{l}\text { Investigation of } \\
\text { lncRNA-protein } \\
\text { interaction }\end{array}$} & RIP & $\begin{array}{l}\text { - Capable to map specific } \\
\text { RNA-Protein complexes } \\
\text { - Higher binding resolution and } \\
\text { low background signal } \\
\text { - No prior knowledge is required }\end{array}$ & $\begin{array}{l}\text { - } \quad \text { Required known protein } \\
\text { specific antibodies } \\
\text { False negative result can } \\
\text { be generated } \\
\text { - } \quad \begin{array}{l}\text { Nonspecific antibodies } \\
\text { cannot be used }\end{array}\end{array}$ & [163-166] \\
\hline & PAR-CLIP & $\begin{array}{ll}\text { - } & \text { Provides efficient mapping of } \\
\text { RNA-protein interaction } \\
\text { - } & \text { Decreased signal-to-noise ratio } \\
\text { - } & \text { Develop specific } \\
& \text { sequence mutations }\end{array}$ & $\begin{array}{l}\text { - } \quad \text { Limited to in vitro study } \\
\text { Pull-down of } \\
\text { non-specific protein }\end{array}$ & [171-173] \\
\hline
\end{tabular}

4.3.1. Localization of lncRNA: Single-Molecule RNA Fluorescence In Situ Hybridization (smRNA-FISH)

RNA fluorescence in situ hybridization (RNA-FISH) is a conventional method that si commonly used to detect the subcellular localization of lncRNAs [146,174]. Despite being able to identify the subcellular location of lncRNA, RNA-FISH has several limitations, for example, relatively low sensitivity and limitation to cover the comparatively highly abundant lncRNAs in the cells only [85,174]. Therefore, smRNA-FISH was then developed to quantify the absolute level of lncRNAs and the subcellular localization of low-abundance lncRNAs [19,149,150,175]. Yet, smRNA-FISH still has several drawbacks, including off-target hybridization, which needed to be improved for better understanding the lncRNAs functions. 


\subsubsection{Techniques for Investigating lncRNA-DNA Interaction}

Capture Hybridization Analysis of RNA Target (CHART)

CHART is a powerful method for mapping the genome-wide binding profile of chromatinassociated RNAs [151]. It utilizes a short number of 22-28 nt complementary biotinylated oligonucleotides that allow for the detection of lncRNAs of interest and its associated genomic DNA and/or protein from formaldehyde cross-linked chromatin [151,152]. In this method, designed probe can only target the region of potential binding sites instead of covering the entire length of lncRNA to capture the target complexes, hence the background signals can be reduced [86]. Along with the several advantages, it also comes with some shortcomings, such as using inefficient cross-linking agent formaldehyde and being time consuming, as time for digestion is required.

\section{Chromatin Isolation by RNA Purification (ChIRP)}

ChIRP utilizes a combination of oligonucleotides-based RNA-centric pull-down method with high-throughput DNA sequencing to disclose the unbiased lncRNA-DNA-protein complex [154]. ChIRP is one of the most commonly used techniques for analyzing chromatin associated lncRNAs. For example, HOTAIR associated chromatin DNA region (GA-rich-DNA-motif to nucleate broad domains of polycomb occupancy and histone 3 lysine 27 trimethylation (H3K27me3)) was analyzed while using ChIRP [155]. Similarly, genomic occupancy of roX2 RNA and telomerase RNA component were also discovered by ChIRP-seq [155]. Despite having the capacity of analyzing the genome-wide lncRNA-DNA binding sites and off target effect reduction, ChIRP has several disadvantages, such as higher noise-to signal ratio $[155,176]$.

\section{RNA Antisense Purification (RAP)}

RAP is an alternative method for mapping the interactions between lncRNAs and chromatin while using antisense biotinylated oligonucleotides mediated hybridization [156]. RAP utilizes larger antisense RNA probe that can cover the full length of interested when compared to other techniques like ChIRP. It provides higher binding affinity and reduces the signal-to-noise ratio $[86,157]$. For example, RAP method was used to identified Xist binding site on X-chromosome [157].

\subsubsection{Techniques for Investigating lncRNA-RNA Interaction}

RNA Antisense purification Followed by RNA Sequencing (RAP-RNA)

RAP-RNA is an improved version of RAP technique that can be used to identify RNA-RNA interactions by utilizing different cross-linking methods. There are three versions of the RAP-RNA method available: RAP-RNA ${ }^{[\mathrm{AMT}]}$, RAP-RNA ${ }^{[\mathrm{FA}]}$, and RAP-RNA ${ }^{[\mathrm{FA}-\mathrm{DSG}]}$ for analyzing the RNA-RNA interactions [158]. For example, RAP-RNA ${ }^{[\mathrm{AMT}]}$ is commonly used to detect the RNA-RNA interactions (those RNAs are directly binding each other exclusive of protein intermediate) by generating aminomethyltrioxalen (AMT) mediated specific uridine bases cross-links [158]. Instead, another cross-linker, named formaldehyde (FA), is used to detect both direct and indirect interactions between RNA species, which is known as RAP-RNA ${ }^{[\mathrm{FA}]}$. Finally, an advanced subtype of RAP-RNA has been developed by using multiple cross-linkers FA and disuccinimidyl glutarate (FA-DSC) which known as RAP-RNA ${ }^{[F A-D S G]}$. It provides a stronger cross-link and it can detect RNA-RNA interactions, even though multiplex protein complexes bound the RNAs [158].

Cross-Linking, Ligation and Sequencing of Hybrids (CLASH)

CLASH is an alternative method for mapping RNA-RNA interaction by using UV cross-linking [159,160]. This method is efficient in identifying snoRNA-rRNA and mRNA-miRNA interactions in yeast and human, respectively $[159,160]$. CLASH has several advantages, such as no 
protein-protein crosslinked as like chemically cross-linked methods. However, poor ligation rates of RNA and the incapability of IncRNAs interaction investigation are observed [159].

\subsubsection{Techniques for Investigating lncRNA-Protein Interaction}

RNA Immunoprecipitation (RIP)

RIP is the most widely used method to investigate lncRNA-protein interaction in both in vitro and in vivo [163,164]. In principle, RIP is an antibodies-based technique, where RNA-binding protein of interest specific antibodies are employed, and then RNase digestion and IncRNA-protein complex extraction are performed. Finally, cDNA is synthesized by reverse transcription and, subsequently, high-throughput sequencing, such as, NGS is performed, which provides a single based resolution of protein-bound-RNA [164-166]. Remarkably, the cross linking process is not obligatory, but it can be used in RIP to capture both direct and indirect bound RNA-protein interactions, respectively [166]. This method has been used to investigate lncRNA-protein interactions. For example, lncRNA-Xist interaction with different proteins, named SUZ12 polycomb repressive complex 2 subunit (Suz12), $\mathrm{RbAp} 48$, and embryonic ectoderm development (EeD), was discovered while using the RIP system [177].

High-Throughput Sequencing of RNA Isolated by Cross-Linking Immunoprecipitation (HITS-CLIP)

In HITS-CLIP method, UV-mediated crosslinking forms a covalent bond between RNA and amino acids (AAs) [168-170]. The CLIP-sequence was first applied. A set of lncRNA bound to RB binding protein 4, chromatin remodeling factor (RBBP4), and enhancer of polycomb homolog 2 (EPC2) proteins was discovered [167]. The limitations of this method include mutation due to the use of UV crosslinking and failure to provide full length transcripts sequence [170].

Photoactivatable Ribonucleotide-Enhanced Cross Linking and Immunoprecipitation (PAR-CLIP)

PAR-CLIP is a modified technique from HITS-CLIP with improved crosslinking efficiency and single nucleotide resolution capacity $[171,172]$. PAR-CLIP utilizes multiple crosslinking agents, such as photoreactive ribonucleotide analogs, 6-thioguanosine (6SG), and 4-thiouridine (4SU), which provide stronger crosslinking efficiency between protein and RNAs. Importantly, the use of these crosslinking reagents also improve the limitations of other methods such as photoreactive ribonucleotide analogs hinders the UV-mediated structural change, 4SU and 6SG improve the sequence specific mutations $\mathrm{T}$ to $\mathrm{C}$ and $\mathrm{G}$ to $\mathrm{A}$, respectively [171-173]. This method allows for detecting specific binding sites of RNA-protein complex with higher resolution, but decreased signal-to-noise ratio [86].

\section{Functional Involvement of IncRNAs in Endothelial Dysfunction-Associated Diseases}

IncRNAs have been identified as the key regulators in many biological and pathological processes over the past decades, including impaired endothelial function. A general perspective of the diverse regulatory mechanisms of lncRNAs has been described previously. In this chapter, we closely focus on the functional involvements of lncRNAs in ED-associated diseases, such as abnormal angiogenesis, diabetes, hypertension, and atherosclerosis (Figure 3). It should be reminded that many lncRNAs genes whose expression has positive effects on the expression of other genes might be conferred by the lncRNA gene promoter (ie, enhancer effects in cis) rather than by the lncRNA itself. 


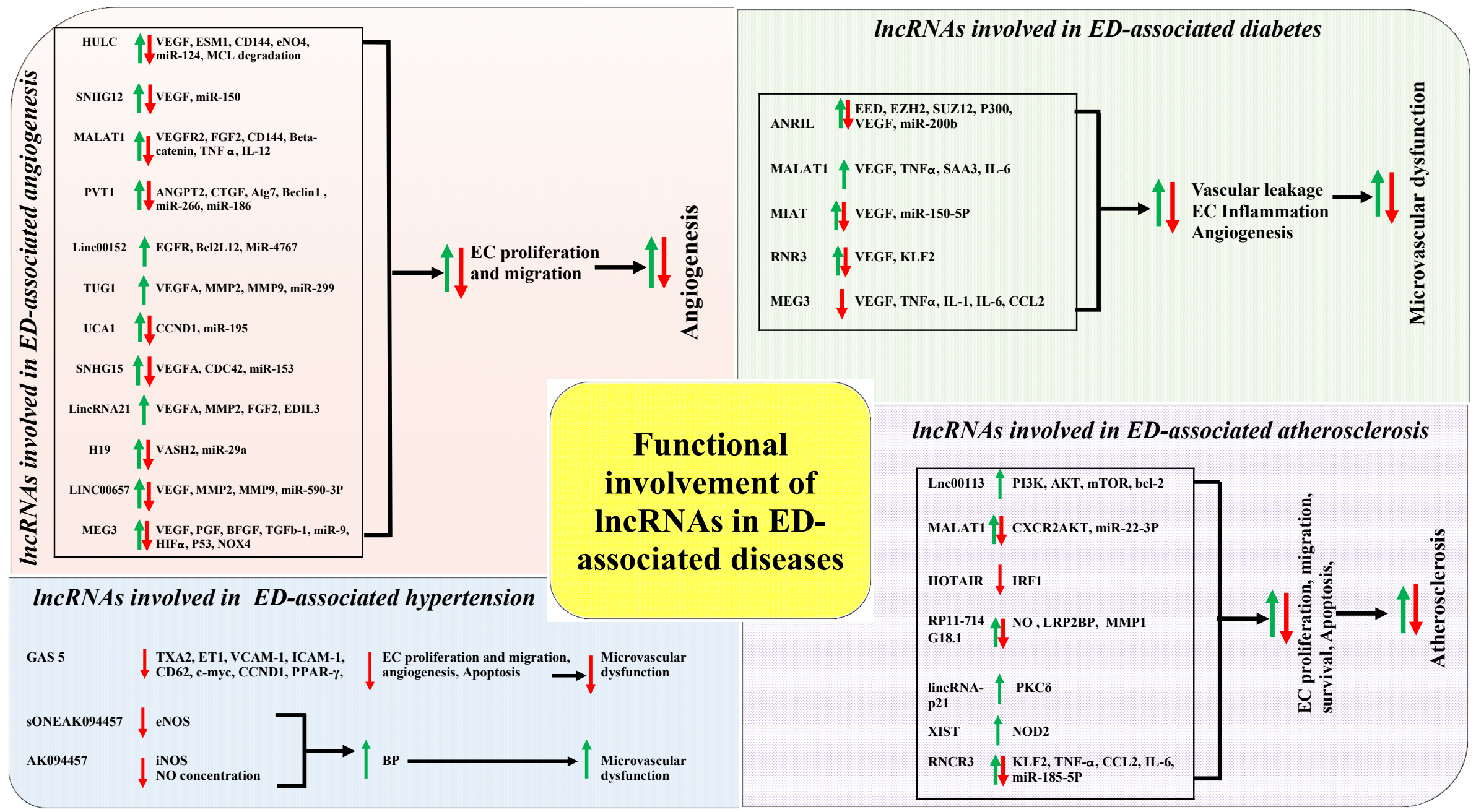

Figure 3. The correlations of functional involvements of long non-coding RNAs (lncRNAs) in abnormal angiogenesis, hypertension, atherosclerosis, and diabetes. Green arrows represent up-regulation and red arrows represent down regulation/ inhibition. All abbreviations mentioned in the figure are spelled out in the end of the article. 


\subsection{The Correlations of Functional Involvement of $\operatorname{lncRNAs}$ in ED and Angiogenesis}

Angiogenesis is defined as the process of new blood vessel formation from a pre-existing vascular network. The complex process of angiogenesis is predominantly controlled by the precise balance of different stimulating and inhibitory factors, such as VEGFs and their receptors [178]. The dysregulation of angiogenesis process was found to be associated with different life-threating diseases, such as haemangioma and growth restriction of newborn babies, placental insufficiency during pregnancy, cardiovascular disease (CVD), cancer progression and metastasis, and rheumatoid arthritis [179]. It has been revealed that the molecular mechanisms of abnormal angiogenesis are mainly depended on the disease types and conditions. An example is hypoxia regulates sprouting angiogenesis in cancer through multiple pathways [180]. In the hypoxic condition, cancer cells extensively secrete VEGF-A that bind with VEGF receptor 2 (VEGFR2) and subsequently promote tumor angiogenesis through enhanced EC proliferation, increased migration via PI3K/AKT/mammalian target of rapamycin (mTOR)/mitogen-activated protein kinases (MAPK), and increased nuclear factor kappa-light-chain-enhancer of activated B cells (NFkB) signalling pathways [181]. Another example is the endothelial progenitor cell (EPC), VSMC, and mesenchymal stem cell (MSC) being critically involved in the angiogenesis progression via regulating the expression of different proangiogenic cytokines, growth factors, angiogenic mediators (such as VEGF, TNF- $\alpha$, IL-1 $\beta$ ), and affecting the differentiation efficiency of EC from MSC [182,183].

Over the past couple of decades, extensive researches had utilized the regulatory process of angiogenesis to establish promising therapeutic strategies in complex disease management. For example, strategies for inhibiting angiogenesis were beneficial for cancer, haemangioma, and corneal neovascularization treatment [184]. On the contrary, angiogenesis stimulation was helpful in placental insufficiency, regenerative disorders, and tissue engineering management [185]. More recently, several lncRNAs were found correlated in the regulation of EC functions and angiogenesis gene expression at their transcriptional and post translational levels, and thus possibly intervening the modulation of angiogenesis process and its associated disease development and progression (Table 4).

Table 4. The correlations of the functional involvement of different lncRNAs in ED and angiogenesis. HULC: Highly upregulated in liver cancer; ESM-1: endothelial cell specific molecule; PI3K: Phosphatidylinositol 3-kinase; Akt: AKT serine/threonine kinase 1; EC: Endothelial cell; SNHG12: Small nucleolar RNA host gene 12; OGD: oxygen-glucose deprivation; VEGF: Vascular endothelial growth factor; MALAT1: Metastasis associated lung adenocarcinoma transcript 1; SMMECs: Skeletal muscle microvascular endothelial cells; VEGFR2: VEGF receptor 2; TAMs: Tumor-associated macrophages; ERK: extracellular signal-regulated kinase; MMP: Matrix metalloproteinase; FAK: Focal adhesion kinase; FGF2: Fibroblast Growth Factor 2; UBE2CP3: Ubiquitin conjugating enzyme E2 C pseudogene 3; VEGFA: Vascular endothelial growth factor A; ERK1: Extracellular signal-regulated kinase 1; HIF-1 $\alpha$ : hypoxia inducible factor 1 subunit alpha; PVT1: Plasmacytoma variant translocation 1; CTGF: connective tissue growth factor; ANGPT2: angiopoietin 2; HUVECs: Human umbilical vein endothelial cells; VEC: vascular endothelial cells; oxLDL: oxidized low-density lipoprotein; TUG1: Taurine up-regulated 1; UCA1: Urothelial cancer associated 1; HMEC: Human microvascular endothelial cells; MEK: Mitogen-activated protein kinase kinase; MEG3: Maternally expressed 3; RBMVECs; Rat brain microvascular endothelial cells; NOX4: NADPH Oxidase 4; Cdc42: cell division cycle 42; HOTAIR: HOX transcript antisense RNA; GRP78: glucose regulated protein 78.

\begin{tabular}{|c|c|c|c|c|}
\hline Name & Location & Disease Association & $\begin{array}{l}\text { Correlations of the Functional Involvement of } \\
\text { lncRNAs in ED and Angiogenesis }\end{array}$ & References \\
\hline \multirow[t]{2}{*}{ HULC } & \multirow[t]{2}{*}{$6 \mathrm{p} 24.3$} & Gliomas & $\begin{array}{c}\text { Promotes angiogenesis through regulating } \\
\text { endothelial cell specific molecule } 1 \text { (ESM-1) via } \\
\text { PI3K/AKT/mTOR pathway }\end{array}$ & [49] \\
\hline & & Angiogenesis & Regulates EC angiogenesis via sequestrating miR-124 & [50] \\
\hline $\begin{array}{l}\text { Small nucleolar } \\
\text { RNA host gene } 12 \\
\text { (SNHG12) }\end{array}$ & $1 \mathrm{p} 35.3$ & Ischemic stroke & $\begin{array}{l}\text { Promotes angiogenesis of oxygen-glucose } \\
\text { deprivation (OGD)-treated brain microvascular EC } \\
\text { through regulating miR-150/VEGF pathway }\end{array}$ & [186] \\
\hline
\end{tabular}


Table 4. Cont

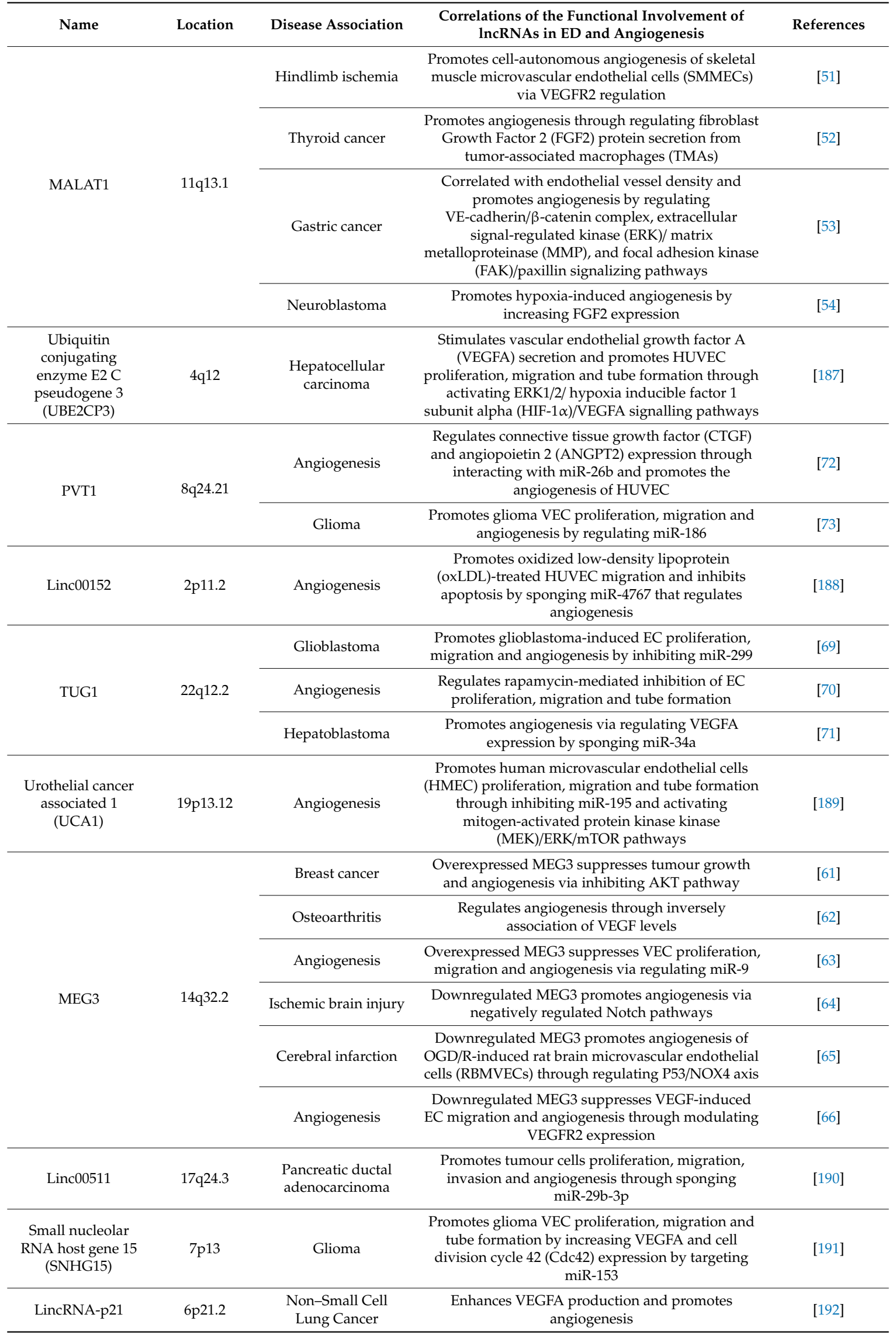


Table 4. Cont.

\begin{tabular}{ccccc}
\hline Name & Location & Disease Association & $\begin{array}{c}\text { Correlations of the Functional Involvement of } \\
\text { lncRNAs in ED and Angiogenesis }\end{array}$ & References \\
\hline ANRIL & $9 \mathrm{p} 21.3$ & Diabetes mellitus & $\begin{array}{c}\text { Overexpressed ANRIL promotes angiogenesis by } \\
\text { increasing VEGF expression via activating NF-kB } \\
\text { pathway }\end{array}$ \\
\hline HOTAIR & $12 \mathrm{q} 13.13$ & $\begin{array}{c}\text { Nasopharyngeal } \\
\text { carcinoma }\end{array}$ & $\begin{array}{c}\text { Promotes angiogenesis through upregulating } \\
\text { VEGFA and angiopoietin 2 (Ang2) expression by } \\
\text { glucose regulated protein 78 (GRP78). }\end{array}$ \\
\hline H19 & [1p15.5 & Glioma & $\begin{array}{c}\text { Promotes glioma-induced angiogenesis by } \\
\text { increasing miR-29a }\end{array}$ \\
\hline LINC00657 & Angiogenesis & $\begin{array}{c}\text { Promotes oxLDL-mediated EC proliferation, } \\
\text { migration and tube formation by interacting with } \\
\text { miR-590-3p and increasing VEGF, MMP-2 and } \\
\text { [8MP-9 expression }\end{array}$ \\
\hline
\end{tabular}

One of the most common intergenic lncRNAs, named as TUG1, is present on chromosome $22 \mathrm{q} 12.2$ and is $7.1 \mathrm{~kb}$ in length. It regulates angiogenesis and it can be found in different types of cancers, including glioblastoma and hepatoblastoma progression [69-71,194]. TUG1 was highly expressed in hepatoblastoma, which is a common malignant hepatic tumour in children, and it was also associated with an increased risk of tumour metastasis $[195,196]$. In Dong's research group study, they demonstrated that TUG1 promotes tumour angiogenesis via up-regulating the expression level of VEGFA by sponging miR-34a [71]. TUG1 is suggested as a potential target to combat the abnormal angiogenesis and improve hepatoblastoma treatment.

Among the angiogenesis promoting lncRNAs, there is one lncRNA, named MEG3, $1.6 \mathrm{~kb}$ in length and is present in chromosome 14q32.3 [197], which was found to be negatively correlated with the progression of disease-related angiogenesis. For example, overexpressed MEG3 suppressed breast cancer cell proliferation, invasion, and angiogenesis through the AKT pathway [61]. Similarly, overexpressed MEG3 inhibited osteoarthritis, ischemic brain injury, and cerebral infarction mediated angiogenesis through the alternation of EC functions via regulating the expression levels of VEGF, VEGFR2, notch signalling pathways, and P53/ NADPH Oxidase 4 (NOX4) axis, respectively [62-66]. Taking together, some lncRNAs can be considered as potential targets for regulating EC function and new vessel formation to abate the development and the progression of angiogenesis-related multifaceted diseases.

\subsection{The Correlations of Functional Involvement of $\operatorname{lnc} R N A$ s in ED and Diabetes}

Diabetes mellitus (DM) is a chronic disorder and it is ranked as the ninth leading cause of the death globally [198]. There is a large amount of evidence showing that both Type-1 DM and Type-2 DM are highly interconnected with ED [199-203]. Hyperglycemia is one of the lethal factors that lead to a reduction in bioavailability of NO and subsequent impaired ED [204,205]. In DM, EC function can be impaired through several mechanisms, such as an alteration in signaling pathways, excessive oxidative stress, activation of pro-inflammatory factors and protein kinase $C$, and mitochondrial dysfunction [206]. Most recently, several genome-wide studies have been revealed the correlations of the functional involvement of different lncRNAs in ED and diabetes (Table 5) $[55-57,67,68,75,79,207,208]$. 
Table 5. The correlations of the functional involvement of different lncRNAs in ED and diabetes. DM: Diabetes mellitus; IL-6: interleukin-6; TNF- $\alpha$ : Tumor necrosis factor- $\alpha$; SAA3: Serum amyloid antigen3; MAPK: mitogen-activated protein kinases; PI3K: Phosphatidylinositol 3-kinase; Akt: AKT serine/threonine kinase 1; CeRNA: competing endogenous RNA; MIAT: Myocardial infarction associated transcript; RNCR3: Retinal non-coding RNA3; KLF2: Kruppel like factor 2.

\begin{tabular}{|c|c|c|}
\hline IncRNA & Correlations of the Functional Involvement of IncRNAs in ED and Diabetes & References \\
\hline ANRIL & $\begin{array}{l}\text { Up-regulated in DM and alters the EC function through increasing VEGF expression } \\
\text { by P300/miR200b/EZH2 }\end{array}$ & [75] \\
\hline MALAT1 & $\begin{array}{l}\text { Highly expressed in DM and upregulates inflammatory mediators IL-6 \& TNF- } \alpha \\
\text { through activating SAA3 and that stimulates DM-induced EC dysfunction via } \\
\text { p38MAPK signaling pathway }\end{array}$ & [55-57] \\
\hline MEG3 & $\begin{array}{l}\text { Down-expressed in DM and enhances DM-mediated EC dysfunctions through } \\
\text { altering PI3K/Akt signaling pathway }\end{array}$ & {$[67,68]$} \\
\hline $\begin{array}{c}\text { Myocardial infarction } \\
\text { associated transcript (MIAT) }\end{array}$ & $\begin{array}{l}\text { Induces DM induced EC dysfunction by acting as a competing endogenous RNA } \\
\text { (CeRNA) via MIAT/miR-150-5p/VEGF network }\end{array}$ & [209] \\
\hline RNCR3 & $\begin{array}{l}\text { Up-regulated in DM and stimulates DM-induced retinal EC dysfunction through } \\
\text { regulating RNCR3/ Kruppel like factor } 2 \text { (KLF2)/miR-185-5p pathway }\end{array}$ & [79] \\
\hline
\end{tabular}

One of the most common intergenic lncRNAs, named MALAT1, which is located on chromosome 11q13.1 and $7 \mathrm{~kb}$ in size, has been functionally identified and characterized in ED-associated diabetes [55]. In that study, MALAT1 was significantly up-regulated in DM. The knockdown of MALAT1 can alter the retinal EC proliferation, migration, and tube formation through interacting with the p38MAPK signaling pathway [55]. Besides, DM with highly expressed MALAT1 who can upregulate serum amyloid antigen3 (SAA3) and stimulate EC inflammation through inflammatory mediators IL-6 and TNF- $\alpha[56,57]$. This indicates the upexpressed MALAT1 induced by diabetes might represent an important regulator of EC in DM and it can possibly act as a novel therapeutic target to lessen the burden that is induced by the vascular complication of ED-associated diabetes. Apart from MALAT1, another IncRNA, named MEG3, regulates EC function through activating the PI3K/Akt signaling pathway under hyperglycemic and oxidative stress condition $[67,68]$.

\subsection{The Correlations of Functional Involvement of IncRNAs in ED and Hypertension}

Hypertension is one of the most important risk factors for CVDs. Studies revealed that vascular endothelium nicotinamide adenine dinucleotide phosphate (NADPH) oxidase, excessive production of mitochondrial ROS, and decreased NO bioavailability were intercorrelated with the impairment of EC function [206,210-212]. Hypertension associated VEC dysfunction is modulated by both local and systemic inflammation, and it subsequently stimulates the activated complement factor 3 (C3) [213]. Afterwards, the activated C3 augment the activity of EPC and C-reactive protein, which consequently leads to vascular damage [213-215]. The number of lncRNA that could be identified in hypertension-associated EC dysfunction is limited when compared to other form of diseases-associated EC dysfunction, but still some lncRNAs have been identified. For example, one of the well-known lncRNAs GAS5, which is located on chromosome 1q25.1 and is widely expressed in different tissues in regulating diverse biological processes, such as cell proliferation, cell growth arrest, and cell apoptosis [36,216,217]. It also regulates vascular remodeling in hypertension [218]. Mechanistically, GAS5 regulates EC and VSMC function in both in vitro and in vivo through interacting with $\beta$-cantenin signaling activity [218]. Another study also demonstrated that a traditional Chinese medicine, $L$. barbarum, carries anti-hypertensive effect in both in vitro and in vivo by reducing the blood pressure through up-regulating the expression level of eNOS via suppressing lncRNA sONE, [219]. Similarly, another traditional Asian medicine, named Notoginsenoside R1 (NR1), reduces blood pressure through stimulating the production of $\mathrm{NO}$ via increasing the phosphorylation of the inducible $\mathrm{NO}$ synthase (iNOS) in EC of the hypertensive animal model. NR1 also down-regulates the overexpressed lncRNA AK094457 in VEC induced the higher expression of iNOS and NO concentration, which leads to the subsequent reduction in blood pressure in hypertensive animal model [220]. 


\subsection{The Correlations of Functional Involvement of IncRNAs in ED and Atherosclerosis}

Atherosclerosis is a large arteries disorder that is considered to be one of the major causes of CVD [221]. It is generally characterized by the development of atherosclerotic plaques in the arterial intima due to the thickening and loss of artery walls elasticity [222,223]. ED has long been considered as the early marker for atherosclerosis, which can be detected before the onset of structural changes [224]. When the endothelial layer is injured at arterial branches, the decreased eNOS expression and increased NF-KB expression lead to subsequent infiltration of LDLs, leukocytes adhesion, and inflammatory response [225]. The infiltration of LDL enhances the monocytes recruitment at the injured site of arterials walls and stimulates chronic inflammation response, thus inducing atherosclerotic plaques formation [226,227]. Moreover, the activated VSMCs were highly proliferated during impaired function of EC, which leads to the thickening and stiffening of arterial walls [228]. The EC functions might be regulated by diverse lncRNAs and potentially involved in the modulation of different vascular diseases development and progression (Table 6) [229].

Table 6. The correlations of the functional involvement of different lncRNAs in ED and atherosclerosis. EC: Endothelial cells; PI3K: Phosphatidylinositol 3-kinase; Akt: AKT serine/threonine kinase 1; mTOR: Mammalian target of rapamycin; MALAT1: Metastasis associated lung adenocarcinoma transcript 1; oxLDL: oxidized low-density lipoprotein; CXCR2: C-X-C Motif Chemokine Receptor 2; HOTAIR: HOX transcript antisense RNA; TSLP: thymic stromal lymphopoietin; LRP2BP: LRP2 binding protein; MMP1: matrix metallopeptidase 1; LOX-1: Lysyl oxidase-like 1; PKC ; protein kinase C delta; NOD2: nucleotide binding oligomerization domain containing 2; CeRNA: competing endogenous RNA; KLF2: Kruppel like factor.

\begin{tabular}{|c|c|c|}
\hline IncRNA. & Correlations of the Functional Involvement of lncRNAs in ED and Atherosclerosis & References \\
\hline Lnc00113 & $\begin{array}{l}\text { Promotes abnormal EC proliferation, survival and migration via activating } \\
\text { PI3K/Akt/mTOR pathway that disrupt EC function and develop atherosclerosis }\end{array}$ & [230] \\
\hline MALAT1 & $\begin{array}{c}\text { Protects EC from ox-LDL-induced EC dysfunction through inhibiting miR-22-3P and } \\
\text { upregulating C-X-C Motif Chemokine Receptor } 2 \text { (CXCR2) \& AKT expression in the } \\
\text { settings of atherosclerosis }\end{array}$ & [58] \\
\hline HOTAIR & $\begin{array}{l}\text { Protect EC from injury and enhance EC proliferation, migration and inhibit apoptosis via } \\
\text { thymic stromal lymphopoietin (TSLP)-PI3K/AKT-HOTAIR pathway that regulates } \\
\text { angiogenesis pathogenesis and progression. }\end{array}$ & [77] \\
\hline RP11-714G18.1 & $\begin{array}{c}\text { Suppresses EC migration through RP11-714G18.1/ LRP2 binding protein (LRP2BP)/MMP1 } \\
\text { signaling pathway that provide athero-defensive role in atherosclerosis-related EC } \\
\text { dysfunction. }\end{array}$ & [231] \\
\hline lincRNA-p21 & $\begin{array}{l}\text { Stimulates ox-LDL-induced EC apoptosis and LOX-1 expression via activation of protein } \\
\text { kinase C delta (PKC } 8 \text { ) that regulates atherosclerosis pathogenesis }\end{array}$ & [232] \\
\hline TCONS_00024652 & $\begin{array}{c}\text { Promotes EC proliferation, migration and angiogenesis via downregulating miR21 } \\
\text { expression that stimulates atherosclerosis progression }\end{array}$ & [233] \\
\hline XIST & $\begin{array}{c}\text { Promotes ox-LDL-mediated EC injury via miR-320/ nucleotide binding oligomerization } \\
\text { domain containing } 2 \text { (NOD2) pathway and modulates atherosclerosis }\end{array}$ & [80] \\
\hline RNCR3 & $\begin{array}{l}\text { Regulates EC function and accelerates atheroprotective function to the endothelium via } \\
\text { acting as a ceRNA and forming a feedback loop with KLF2 and miR-185-5p }\end{array}$ & [78] \\
\hline
\end{tabular}

An intergenic lncRNA, RNCR3, was found to be significantly up-regulated in both human and mouse aorta atherosclerotic lesion and it accelerates atheroprotective function to the endothelium [78]. In mice models (ApoE-/- and C57BL/6J), the knockdown of RNCR3 promotes atherosclerosis development via aggravated hypercholesterolemia and excessive inflammatory factors release. [78]. Similarly, a lncRNA, named TCONS_00024652, stimulates EC proliferation, migration, and plaque angiogenesis through regulating miR-21 expression, which eventually promotes atherosclerosis progression [233]. All of these established correlations, which suggests potential linkages of the functional involvement of different lncRNAs in ED and atherosclerosis. 


\section{Conclusions}

It is recommended to target the aim of lncRNA study at disease specific or cell specific, rather than performing a gross study to discover the biomarkers for CVD due to the complexity of CVS pathophysiology, the interference of IncRNA in gene expression and signal pathways at various stages. Examples of disease specific lncRNAs include MIAT for acute myocardial infarction (AMI) [234] and myosin heavy chain associated RNA transcript (Mhrt) for heart failure [235]. In the vascular system, endothelial expressed MALAT1 can regulate vessel growth and function [59]. On the other hand, SMC-expressed brain cytoplasmic RNA 1 (BCYRN1) mainly regulates its contractile phenotype [236]. In this regard, we believed that systemic tissue specific or condition specific study of lncRNAs can improve their therapeutic potential in the translational perspective.

We also observed that some identified lncRNAs might be playing critical roles in regulating the development and progression of various ED-associated diseases, and therefore possibly to translate into novel biomarkers and therapeutic targets in ED-associated disease treatments. There is a growing body evidence that suggests that ED is functionally associated with various pathophysiological conditions, including abnormal angiogenesis, hypertension, diabetes, and atherosclerosis, which in turns leads to the increased cardiovascular disease-related deaths. Several lncRNAs were correlated in the regulation of endothelial function and its associated diseases progression. However, the underlying functional mechanisms in the majority of these identified lncRNAs are still not clear. Nevertheless, with the discovery of new advanced technologies mentioned earlier, a massive development was underway in lncRNA biology studies and emerging topics, such as largescale discovery of lncRNAs using genome-wide sequencing methods, the identification of lncRNAs subcellular localization, and the potential interactions of IncRNAs with DNA, RNA, and protein. These will help us to better understand about lncRNAs functions in different biological processes, including endothelial dysfunction and its associated disorders.

Author Contributions: C.L. conceived and designed the review. R.I. drafted the manuscript and prepared the figures and tables. C.L. and R.I. evaluated and revised the manuscript. All authors read and approved the final manuscript.

Funding: No funding was received for this work.

Acknowledgments: The authors would like to thank Ms. Kathy Pang for constructive criticism of the manuscript.

Conflicts of Interest: The authors declare no conflict of interest.

$\begin{array}{ll}\text { Abbreviations } \\ \text { 6SG } & \text { 6-Thioguanosine } \\ \text { 4SU } & \text { 4-Thiouridine } \\ \text { AAs } & \text { Amino acids } \\ \text { ADAR } & \text { Adenosine deaminase acting on RNA } \\ \text { Akt } & \text { AKT serine/threonine kinase 1 } \\ \text { Alu } & \text { Arthrobacter luteus } \\ \text { AMT } & \text { Aminomethyltrioxalen } \\ \text { ANGPT2 } & \text { Angiopoietin 2 } \\ \text { ASOs } & \text { Antisense oligonucleotides } \\ \text { BACE1 } & \text { Beta-secretase 1 } \\ \text { BACE1AS } & \text { BACE1 (beta-secretase 1)-antisense RNA } \\ \text { BCYRN1 } & \text { Brain cytoplasmic RNA 1 } \\ \text { BP } & \text { Blood pressure } \\ \text { CAGE } & \text { Cap analysis of gene expression } \\ \text { CCNA2 } & \text { Cyclin A2 } \\ \text { CCNB1 } & \text { Cyclin B1 } \\ \text { CCNB2 } & \text { Cyclin B2 } \\ \text { Cdc42 } & \text { Cell division cycle 42 }\end{array}$


CeRNA Competing endogenous RNA

CGMP Cyclic guanosine $3^{\prime}, 5^{\prime}$-monophosphate

CHART Capture hybridization analysis of RNA target

ChIRP Chromatin isolation by RNA purification

CLASH Cross-linking, ligation and sequencing of hybrids

COUP-TFII Chicken ovalbumin upstream promoter transcription-factor-2

CRISPRi CRISPR interference

CTD Carboxyl-teminal domain

CTGF Connective tissue growth factor

CVD Cardiovascular disease

CX3CL1 C-X3-C motif chemokine ligand 1

DSC Disuccinimidyl glutarate

EC Endothelial cell

ED Endothelial dysfunction

EDHF Endothelium derived hyperpolarizing factor

EeD Embryonic ectoderm development

ERK Extracellular signal-regulated kinase

ESM-1 Endothelial cell specific molecule

EPC Endothelial progenitor cell

EPC2 Enhancer of polycomb homolog 2

ER Endoplasmic reticulum

ET-1 Endothelin-1

FA Formaldehyde

FAK Focal adhesion kinase

FISH Fluorescence in situ hybridization

FGF2 Fibroblast Growth Factor 2

GAS5 Growth arrest specific 5

GATA-AS Antisense transcript of GATA6

GRP78 Glucose regulated protein 78

GR Glucocorticoid receptor

GTP Guanosine triphosphate

H3K4me2 Demethylation of lysine 4 residue on histone 3

H3K4me3 Trimethylation of lysine 4 of histone $\mathrm{H} 3$

H3K27me3 Histone 3 lysine 27 trimethylation

H19 H19 imprinted maternally expressed transcript

HDR Homology direct repair

HITS-CLIP High-throughput sequencing of RNA isolated by cross-linking immunoprecipitation

HOTAIR HOX transcript antisense RNA

HULC Highly upregulated in liver cancer

IL-6 Interleukin-6

HUVECs Human umbilical vein endothelial cells

IL-1 $\beta \quad$ Interleukin 1 beta

KLF2 Kruppel like factor

KRAB Kruppel-associated box

LDL Low-density lipoprotein

lncRNAs Long non-coding RNAs

LOX2 Lysyl oxidase-like 2

LRP2BP LRP2 binding protein

LSD1 Lys-specific demethylase 1

MALAT1 Metastasis associated lung adenocarcinoma transcript 1

MAPK Mitogen-activated protein kinases

MCP-1 Monocyte chemoattractant protein-1

MEG3 Maternally expressed 3 
MERFISH Multiplexed error-robust fluorescence in situ hybridization

Mhrt Myosin heavy chain associated RNA transcript

MIAT Myocardial infarction associated transcript

MMP Matrix metalloproteinase

MSC Mesenchymal stem cell

mTOR Mammalian target of rapamycin

NADPH Nicotinamide adenine dinucleotide phosphate

NATs Natural antisense transcripts

NFAT Nuclear factor of activated T-cells

NFkB Nuclear factor kappa-light-chain-enhancer of activated B cells

NGS Next generation sequencing

NHEJ Non-homologous end joining

NO Nitric oxide

NOD2 Nucleotide binding oligomerization domain containing 2

eNOS NO synthase

NR1 Notoginsenoside R1

NRON Non-coding repressor of NFAT

NOX4 NADPH Oxidase 4

OGD Oxygen-glucose deprivation

ORF Open reading frame

oxLDL Oxidized low-density lipoprotein

PAR-CLIP Photoactivatable ribonucleotide-enhanced cross linking and immunoprecipitation

PGI2 Prostacyclin

PGH2 ProstaglandinH2

PI3K Phosphatidylinositol 3-kinase

PKC $\quad$ Protein kinase $C$ delta

PolII RNA polymerase II

PRC2 Polycomb repressive complex

PVT1 Plasmacytoma variant translocation 1

RAP RNA antisense purification

RAP-RNA RNA antisense purification followed by RNA sequencing

RBBP4 RB binding protein 4, chromatin remodeling factor

RIP RNA immunoprecipitation

RNA-FISH RNA fluorescence in situ hybridization

RNA-Seq RNA sequencing

RNAi RNA interference

RNCR3 Retinal non-coding RNA3

ROS Reactive oxygen species

SAGE Serial analysis of gene expression

SAA3 Serum amyloid antigen3

sGC Soluble guanylyl cyclase

sgRNA Single guide RNA

shRNA Short hairpin RNA

SINE Short interspersed elements

siRNA Small interfering RNA

SMAD6 Mothers against decapentaplegic homologue 6

smRNA-FISH Single molecule RNA in situ hybridization

SMMECs Skeletal muscle microvascular endothelial cells

SNHG12 Small nucleolar RNA host gene 12

SNHG15 Small nucleolar RNA host gene 15

SOX18 SRY (Sex Determining Region Y)-Box 18

SRY Sex Determining Region Y

Suz12 SUZ12 polycomb repressive complex 2 subunit 


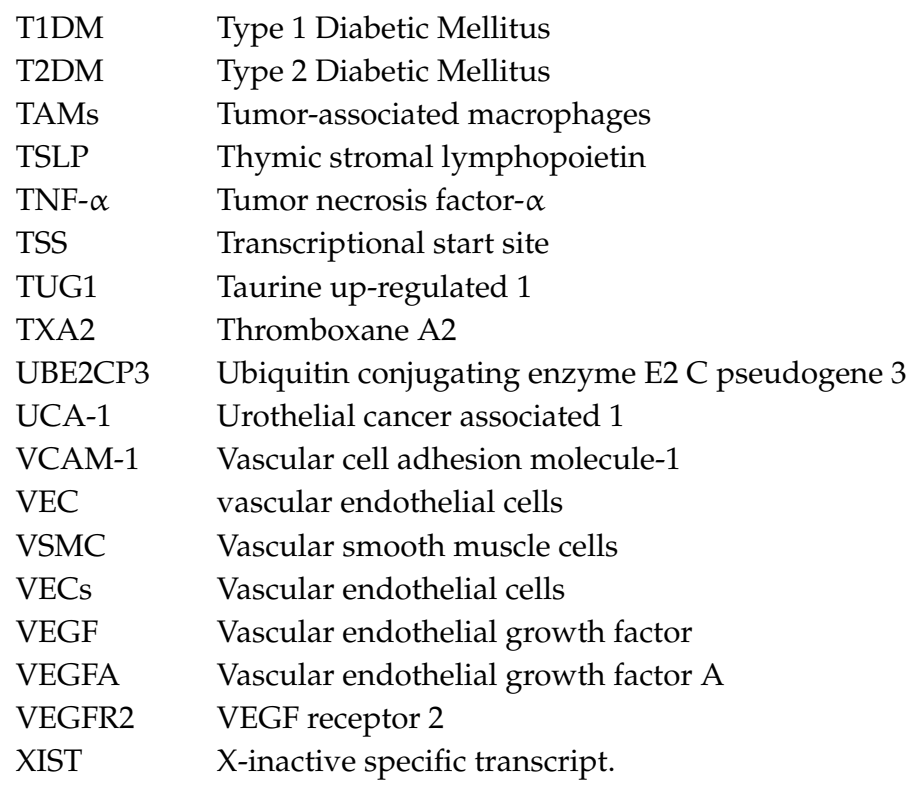

\section{References}

1. Chlopicki, S. Perspectives in pharmacology of endothelium: From bench to bedside. Pharmacol. Rep. PR 2015, 67, vi-ix. [CrossRef] [PubMed]

2. Lerman, A.; Zeiher, A.M. Endothelial function: Cardiac events. Circulation 2005, 1111, 363-368. [CrossRef] [PubMed]

3. Khazaei, M.; Moien-Afshari, F.; Laher, I. Vascular endothelial function in health and diseases. Pathophysiology 2008, 15, 49-67. [CrossRef] [PubMed]

4. Godo, S.; Shimokawa, H. Endothelial functions. Arterioscler. Thromb. Vasc. Biol. 2017, 37, e108-e114. [CrossRef] [PubMed]

5. Deanfield, J.E.; Halcox, J.P.; Rabelink, T.J. Endothelial function and dysfunction: Testing and clinical relevance. Circulation 2007, 115, 1285-1295. [CrossRef] [PubMed]

6. Nafisa, A.; Gray, S.G.; Cao, Y.; Wang, T.; Xu, S.; Wattoo, F.H.; Barras, M.; Cohen, N.; Kamato, D.; Little, P.J. Endothelial function and dysfunction: Impact of metformin. Pharmacol. Ther. 2018, 192, 150-162. [CrossRef] [PubMed]

7. Ghosh, A.; Gao, L.; Thakur, A.; Siu, P.M.; Lai, C.W.K. Role of free fatty acids in endothelial dysfunction. J. Biomed. Sci. 2017, 24, 50. [CrossRef] [PubMed]

8. Schwartz, B.; Economides, C.; Mayeda, G.; Burstein, S.; Kloner, R. The endothelial cell in health and disease: Its function, dysfunction, measurement and therapy. Int. J. Impot. Res. 2010, 22, 77-90. [CrossRef] [PubMed]

9. Djebali, S.; Davis, C.A.; Merkel, A.; Dobin, A.; Lassmann, T.; Mortazavi, A.M.; Tanzer, A.; Lagarde, J.; Lin, W.; Schlesinger, F.; et al. Landscape of transcription in human cells. Nature 2012, 489, 101-108. [CrossRef]

10. Morris, K.V.; Mattick, J.S. The rise of regulatory RNA. Nat. Rev. Genet. 2014, 15, 423-437. [CrossRef]

11. Nagano, T.; Fraser, P. No-nonsense functions for long noncoding RNAs. Cell 2011, 145, 178-181. [CrossRef] [PubMed]

12. Palazzo, A.F.; Lee, E.S. Non-coding RNA: What is functional and what is junk? Front. Genet. 2015, 6, 2. [CrossRef] [PubMed]

13. Christopher, A.F.; Kaur, R.P.; Kaur, G.; Kaur, A.; Gupta, V.; Bansal, P. MicroRNA therapeutics: Discovering novel targets and developing specific therapy. Perspect. Clin. Res. 2016, 7, 68-74. [PubMed]

14. Selleri, L.; Bartolomei, M.S.; Bickmore, W.A.; He, L.; Stubbs, L.; Reik, W.; Barsh, G.S. A Hox-embedded long noncoding RNA: Is it all hot air? PLoS Genet. 2016, 12, e1006485. [CrossRef] [PubMed]

15. Han, X.; Luo, S.; Peng, G.; Lu, J.Y.; Cui, G.; Liu, L.; Yan, P.; Yin, Y.; Liu, W.; Wang, R.; et al. Mouse knockout models reveal largely dispensable but context-dependent functions of lncRNAs during development. J. Mol. Cell Biol. 2018, 10, 175-178. [CrossRef] [PubMed] 
16. Sauvageau, M.; Goff, L.A.; Lodato, S.; Bonev, B.; Groff, A.F.; Gerhardinger, C.; Sanchez-Gomez, D.B.; Hacisuleyman, E.; Li, E.; Spence, M.; et al. Multiple knockout mouse models reveal lincRNAs are required for life and brain development. eLife 2013, 2, e01749. [CrossRef]

17. Quinn, J.J.; Chang, H.Y. Unique features of long non-coding RNA biogenesis and function. Nat. Rev. Genet. 2016, 17, 47-62. [CrossRef]

18. Laurent, G.S.; Wahlestedt, C.; Kapranov, P. The Landscape of long noncoding RNA classification. Trends Genet. 2015, 31, 239-251. [CrossRef]

19. Cabili, M.N.; Dunagin, M.C.; McClanahan, P.D.; Biaesch, A.; Padovan-Merhar, O.; Regev, A.; Rinn, J.L.; Raj, A. Localization and abundance analysis of human lncRNAs at single-cell and single-molecule resolution. Genome Biol. 2015, 16, 20. [CrossRef]

20. Mercer, T.R.; Dinger, M.E.; Sunkin, S.M.; Mehler, M.F.; Mattick, J.S. Specific expression of long noncoding RNAs in the mouse brain. Proc. Natl. Acad. Sci. USA 2008, 105, 716-721. [CrossRef]

21. Batista, P.J.; Chang, H.Y. Long noncoding RNAs: Cellular address codes in development and disease. Cell 2013, 152, 1298-1307. [CrossRef] [PubMed]

22. Yu, B.; Wang, S. Angio-LncRs: LncRNAs that regulate angiogenesis and vascular disease. Theranostics 2018, 8, 3654-3675. [CrossRef] [PubMed]

23. Geisler, S.; Coller, J. RNA in unexpected places: Long non-coding RNA functions in diverse cellular contexts. Nat. Rev. Mol. Cell Biol. 2013, 14, 699-712. [CrossRef] [PubMed]

24. Tsai, M.-C.; Manor, O.; Wan, Y.; Mosammaparast, N.; Wang, J.K.; Lan, F.; Shi, Y.; Segal, E.; Chang, H.Y. Long noncoding RNA as modular scaffold of histone modification complexes. Science 2010, 329, 689-693. [CrossRef] [PubMed]

25. Kim, T.-K.; Hemberg, M.; Gray, J.M. Enhancer RNAs: A class of long noncoding RNAs synthesized at enhancers. Cold Spring Harb. Perspect. Biol. 2015, 7, a018622. [CrossRef] [PubMed]

26. Li, W.; Notani, D.; Rosenfeld, M.G. Enhancers as non-coding RNA transcription units: Recent insights and future perspectives. Nat. Rev. Genet. 2016, 17, 207-223. [CrossRef] [PubMed]

27. Neumann, P.; Jaé, N.; Knau, A.; Glaser, S.F.; Fouani, Y.; Rossbach, O.; Krüger, M.; John, D.; Bindereif, A.; Grote, P.; et al. The lncRNA GATA6-AS epigenetically regulates endothelial gene expression via interaction with LOXL2. Nat. Commun. 2018, 9, 237. [CrossRef]

28. Khalil, A.M.; Guttman, M.; Huarte, M.; Garber, M.; Raj, A.; Morales, D.R.; Thomas, K.; Presser, A.; Bernstein, B.E.; Van Oudenaarden, A.; et al. Many human large intergenic noncoding RNAs associate with chromatin-modifying complexes and affect gene expression. Proc. Natl. Acad. Sci. USA 2009, 106, 11667-11672. [CrossRef]

29. Rinn, J.L.; Chang, H.Y. Genome regulation by long noncoding RNAs. Annu. Rev. Biochem. 2012, 81, 145-166. [CrossRef]

30. Dykes, I.M.; Emanueli, C. Transcriptional and post-transcriptional gene regulation by long non-coding RNA. Genom. Proteom. Bioinform. 2017, 15, 177-186. [CrossRef]

31. Leisegang, M.S.; Fork, C.; Josipovic, I.; Richter, F.M.; Preussner, J.; Hu, J.; Miller, M.J.; Epah, J.; Hofmann, P.; Günther, S.; et al. Long noncoding RNA MANTIS facilitates endothelial angiogenic function. Circulation 2017, 136, 65-79. [CrossRef] [PubMed]

32. Bumgarner, S.L.; Neuert, G.; Voight, B.F.; Symbor-Nagrabska, A.; Grisafi, P.; Van Oudenaarden, A.; Fink, G.R. Single-cell analysis reveals that noncoding RNAs contribute to clonal heterogeneity by modulating transcription factor recruitment. Mol. Cell 2012, 45, 470-482. [CrossRef] [PubMed]

33. Hirota, K.; Miyoshi, T.; Kugou, K.; Hoffman, C.S.; Shibata, T.; Ohta, K. Stepwise chromatin remodelling by a cascade of transcription initiation of non-coding RNAs. Nature 2008, 456, 130-134. [CrossRef] [PubMed]

34. Mariner, P.D.; Walters, R.D.; Espinoza, C.A.; Drullinger, L.F.; Wagner, S.D.; Kugel, J.F.; Goodrich, J.A. Human Alu RNA is a modular transacting repressor of mRNA transcription during heat shock. Mol. Cell 2008, 29, 499-509. [CrossRef] [PubMed]

35. Martianov, I.; Ramadass, A.; Barros, A.S.; Chow, N.; Akoulitchev, A. Repression of the human dihydrofolate reductase gene by a non-coding interfering transcript. Nature 2007, 445, 666-670. [CrossRef]

36. Kino, T.; Hurt, D.E.; Ichijo, T.; Nader, N.; Chrousos, G.P. Noncoding RNA gas5 is a growth arrest-and starvation-associated repressor of the glucocorticoid receptor. Sci. Signal. 2010, 3, ra8. [CrossRef] [PubMed] 
37. Willingham, A.T.; Orth, A.P.; Batalov, S.; Peters, E.C.; Wen, B.G.; Aza-Blanc, P.; Hogenesch, J.B.; Schultz, P.G. A strategy for probing the function of noncoding RNAs finds a repressor of NFAT. Science 2005, 309, 1570-1573. [CrossRef]

38. Moreau, P.R.; Örd, T.; Downes, N.L.; Niskanen, H.; Bouvy-Liivrand, M.; Aavik, E.; Ylä-Herttuala, S.; Kaikkonen, M.U. Transcriptional profiling of hypoxia-regulated non-coding RNAs in human primary endothelial cells. Front. Cardiovasc. Med. 2018, 5, 159. [CrossRef]

39. Faghihi, M.A.; Wahlestedt, C. Regulatory roles of natural antisense transcripts. Nat. Rev. Mol. Cell Biol. 2009, 10, 637-643. [CrossRef]

40. Carrieri, C.; Cimatti, L.; Biagioli, M.; Beugnet, A.; Zucchelli, S.; Fedele, S.; Pesce, E.; Ferrer, I.; Collavin, L.; Santoro, C.; et al. Long non-coding antisense RNA controls Uchl1 translation through an embedded SINEB2 repeat. Nature 2012, 491, 454-457. [CrossRef]

41. Faghihi, M.A.; Modarresi, F.; Khalil, A.M.; Wood, D.E.; Sahagan, B.G.; Morgan, T.E.; Finch, C.E.; Laurent, G.S.; Kenny, P.J.; Wahlestedt, C. Expression of a noncoding RNA is elevated in Alzheimer's disease and drives rapid feed-forward regulation of $\beta$-secretase. Nat. Med. 2008, 14, 723-730. [CrossRef] [PubMed]

42. Faghihi, M.A.; Zhang, M.; Huang, J.; Modarresi, F.; Van Der Brug, M.P.; A Nalls, M.; Cookson, M.R.; St-Laurent, G.; Wahlestedt, C. Evidence for natural antisense transcript-mediated inhibition of microRNA function. Genome Biol. 2010, 11, R56. [CrossRef] [PubMed]

43. Cesana, M.; Cacchiarelli, D.; Legnini, I.; Santini, T.; Sthandier, O.; Chinappi, M.; Tramontano, A.; Bozzoni, I. A long noncoding RNA controls muscle differentiation by functioning as a competing endogenous RNA. Cell 2011, 147, 358-369. [CrossRef] [PubMed]

44. Robb, G.B.; Carson, A.R.; Tai, S.C.; Fish, J.E.; Singh, S.; Yamada, T.; Scherer, S.W.; Nakabayashi, K.; Marsden, P.A.; Scherer, S.; et al. Post-transcriptional regulation of endothelial nitric-oxide synthase by an overlapping antisense mRNA transcript. J. Biol. Chem. 2004, 279, 37982-37996. [CrossRef] [PubMed]

45. Fish, J.E.; Matouk, C.C.; Yeboah, E.; Bevan, S.C.; Khan, M.; Patil, K.; Ohh, M.; Marsden, P.A. Hypoxia-inducible expression of a natural cis-antisense transcript inhibits endothelial nitric-oxide synthase. J. Biol. Chem. 2007, 282, 15652-15666. [CrossRef] [PubMed]

46. Libby, P. Mechanisms of acute coronary syndromes and their implications for therapy. N. Engl. J. Med. 2013, 368, 2004-2013. [CrossRef]

47. Libby, P. Inflammation in atherosclerosis. Arterioscler. Thromb. Vasc. Biol. 2012, 32, 2045-2051. [CrossRef]

48. Mullick, A.E.; Soldau, K.; Kiosses, W.B.; Bell, T.A.; Tobias, P.S.; Curtiss, L.K. Increased endothelial expression of Toll-like receptor 2 at sites of disturbed blood flow exacerbates early atherogenic events. J. Exp. Med. 2008, 205, 373-383. [CrossRef]

49. Zhu, Y.; Zhang, X.; Qi, L.; Cai, Y.; Yang, P.; Xuan, G.; Jiang, Y. HULC long noncoding RNA silencing suppresses angiogenesis by regulating ESM-1 via the PI3K/Akt/mTOR signaling pathway in human gliomas. Oncotarget 2016, 7, 14429-14440. [CrossRef]

50. Yin, D.; Li, Y.; Fu, C.; Feng, Y. Pro-Angiogenic Role of lncRNA HULC in Microvascular Endothelial Cells via Sequestrating miR-124. Cell. Physiol. Biochem. 2018, 50, 2188-2202. [CrossRef]

51. Zhang, X.; Tang, X.; Hamblin, M.H.; Yin, K.-J. Long Non-Coding RNA Malat1 Regulates Angiogenesis in Hindlimb Ischemia. Int. J. Mol. Sci. 2018, 19, 1723. [CrossRef] [PubMed]

52. Huang, J.K.; Ma, L.; Song, W.H.; Lu, B.Y.; Huang, Y.B.; Dong, H.M.; Ma, X.K.; Zhu, Z.Z.; Zhou, R. lncRNA-MALAT1 promotes angiogenesis of thyroid cancer by modulating tumor-associated macrophage FGF2 protein secretion. J. Cell. Biochem. 2017, 118, 4821-4830. [CrossRef] [PubMed]

53. Li, Y.; Wu, Z.; Yuan, J.; Sun, L.; Lin, L.; Huang, N.; Bin, J.; Liao, Y.; Liao, W. Long non-coding RNA MALAT1 promotes gastric cancer tumorigenicity and metastasis by regulating vasculogenic mimicry and angiogenesis. Cancer Lett. 2017, 395, 31-44. [CrossRef] [PubMed]

54. Tee, A.E.; Liu, B.; Song, R.; Li, J.; Pasquier, E.; Cheung, B.B.; Jiang, C.; Marshall, G.M.; Haber, M.; Norris, M.D.; et al. The long noncoding RNA MALAT1 promotes tumor-driven angiogenesis by up-regulating pro-angiogenic gene expression. Oncotarget 2016, 7, 8663-8675. [CrossRef] [PubMed]

55. Liu, J.-Y.; Yao, J.; Li, X.-M.; Song, Y.-C.; Wang, X.-Q.; Li, Y.-J.; Yan, B.; Jiang, Q. Pathogenic role of lncRNA-MALAT1 in endothelial cell dysfunction in diabetes mellitus. Cell Death Dis. 2014, 5, e1506. [CrossRef] [PubMed] 
56. Puthanveetil, P.; Chen, S.; Feng, B.; Gautam, A.; Chakrabarti, S. Long non-coding RNA MALAT 1 regulates hyperglycaemia induced inflammatory process in the endothelial cells. J. Cell. Mol. Med. 2015, 19, 1418-1425. [CrossRef] [PubMed]

57. Wu, D.; Cheng, Y.G.; Huang, X.; Zhong, M.W.; Liu, S.Z.; Hu, S.Y. Downregulation of lncRNA MALAT1 contributes to renal functional improvement after duodenal-jejunal bypass in a diabetic rat model. J. Physiol. Biochem. 2018, 74, 431-439. [CrossRef] [PubMed]

58. Tang, Y.; Jin, X.; Xiang, Y.; Chen, Y.; Shen, C.-X.; Zhang, Y.-C.; Li, Y.-G. The lncRNA MALAT1 protects the endothelium against ox-LDL-induced dysfunction via upregulating the expression of the miR-22-3p target genes CXCR2 and AKT. FEBS Lett. 2015, 589, 3189-3196. [CrossRef]

59. Michalik, K.M.; You, X.; Manavski, Y.; Doddaballapur, A.; Zörnig, M.; Braun, T.; John, D.; Ponomareva, Y.; Chen, W.; Uchida, S.; et al. Long noncoding RNA MALAT1 regulates endothelial cell function and vessel growth. Circ. Res. 2014, 114, 1389-1397. [CrossRef] [PubMed]

60. Xin, J.-W.; Jiang, Y.-G. Long noncoding RNA MALAT1 inhibits apoptosis induced by oxygen-glucose deprivation and reoxygenation in human brain microvascular endothelial cells. Exp. Ther. Med. 2017, 13, 1225-1234. [CrossRef]

61. Zhang, C.Y.; Yu, M.S.; Li, X.; Zhang, Z.; Han, C.R.; Yan, B. Overexpression of long non-coding RNA MEG3 suppresses breast cancer cell proliferation, invasion, and angiogenesis through AKT pathway. Tumor Biol. 2017, 39, 1010428317701311. [CrossRef] [PubMed]

62. Su, W.; Xie, W.; Shang, Q.; Su, B. The long noncoding RNA MEG3 is downregulated and inversely associated with VEGF levels in osteoarthritis. BioMed Res. Int. 2015, 2015, 356893. [CrossRef] [PubMed]

63. He, C.; Yang, W.; Yang, J.; Ding, J.; Li, S.; Wu, H.; Zhou, F.; Jiang, Y.; Teng, L.; Yang, J. Long noncoding RNA MEG3 negatively regulates proliferation and angiogenesis in vascular endothelial cells. DNA Cell Biol. 2017, 36, 475-481. [CrossRef] [PubMed]

64. Liu, J.; Li, Q.; Zhang, K.S.; Hu, B.; Niu, X.; Zhou, S.M.; Li, S.G.; Luo, Y.P.; Wang, Y.; Deng, Z.F. Downregulation of the long non-coding RNA Meg3 promotes angiogenesis after ischemic brain injury by activating notch signaling. Mol. Neurobiol. 2017, 54, 8179-8190. [CrossRef] [PubMed]

65. Liu, J.; Li, Q.; Zhang, K.S.; Hu, B.; Niu, X.; Zhou, S.M.; Li, S.G.; Luo, Y.P.; Wang, Y.; Deng, Z.F. Long noncoding RNA MEG3 mediated angiogenesis after cerebral infarction through regulating p53/NOX4 axis. Biochem. Biophys. Res. Commun. 2017, 490, 700-706.

66. Ruan, W.; Zhao, F.; Zhao, S.; Zhang, L.; Shi, L.; Pang, T. Knockdown of long noncoding RNA MEG3 impairs VEGF-stimulated endothelial sprouting angiogenesis via modulating VEGFR2 expression in human umbilical vein endothelial cells. Gene 2018, 649, 32-39. [CrossRef]

67. Qiu, G.-Z.; Tian, W.; Fu, H.-T.; Li, C.-P.; Liu, B. Long noncoding RNA-MEG3 is involved in diabetes mellitus-related microvascular dysfunction. Biochem. Biophys. Res. Commun. 2016, 471, 135-141. [CrossRef]

68. Wang, Z.Q.; Di, L.L.; Zhu, J.; Sun, Y.X.; Wang, L.; Liu, L.N. Long non-coding RNA MEG3 mediates high glucose-induced endothelial cell dysfunction. Int. J. Clin. Exp. Pathol. 2018, 11, 1088-1100.

69. Cai, H.; Liu, X.; Zheng, J.; Xue, Y.; Ma, J.; Li, Z.; Xi, Z.; Bao, M.; Liu, Y. Long non-coding RNA taurine upregulated 1 enhances tumor-induced angiogenesis through inhibiting microRNA-299 in human glioblastoma. Oncogene 2017, 36, 318-331. [CrossRef]

70. Gao, X.; Zhang, T.; Zeng, X.; Li, G.; Du, L.; Ma, Z.; Wan, J.; Yang, Y. Effect of silencing lncRNATUG1 on rapamycin-induced inhibition of endothelial cell proliferation and migration. Exp. Ther. Med. 2018, 16, 1891-1899. [CrossRef]

71. Dong, R.; Liu, G.-B.; Liu, B.-H.; Chen, G.; Li, K.; Zheng, S.; Dong, K.-R. Targeting long non-coding RNA-TUG1 inhibits tumor growth and angiogenesis in hepatoblastoma. Cell Death Dis. 2016, 7, e2278. [CrossRef] [PubMed]

72. Zheng, J.; Hu, L.; Cheng, J.; Xu, J.; Zhong, Z.; Yang, Y.; Yuan, Z. lncRNA PVT1 promotes the angiogenesis of vascular endothelial cell by targeting miR-26b to activate CTGF/ANGPT2. Int. J. Mol. Med. 2018, 42, 489-496. [CrossRef] [PubMed]

73. Ma, Y.; Wang, P.; Xue, Y.; Qu, C.; Zheng, J.; Liu, X.; Ma, J.; Liu, Y. PVT1 affects growth of glioma microvascular endothelial cells by negatively regulating miR-186. Tumor Biol. 2017, 39, 1010428317694326. [CrossRef] [PubMed] 
74. Zhang, B.; Wang, D.; Ji, T.F.; Shi, L.; Yu, J.L. Overexpression of lncRNA ANRIL up-regulates VEGF expression and promotes angiogenesis of diabetes mellitus combined with cerebral infarction by activating NF- $\mathrm{kB}$ signaling pathway in a rat model. Oncotarget 2017, 8, 17347-17359. [CrossRef] [PubMed]

75. Thomas, A.A.; Feng, B.; Chakrabarti, S. ANRIL: A regulator of VEGF in diabetic retinopathy. Investig. Ophthalmol. Vis. Sci. 2017, 58, 470-480. [CrossRef] [PubMed]

76. Fu, W.M.; Lu, Y.F.; Hu, B.G.; Liang, W.C.; Zhu, X.; Yang, H.D.; Li, G.; Zhang, J.F. Long noncoding RNA Hotair mediated angiogenesis in nasopharyngeal carcinoma by direct and indirect signaling pathways. Oncotarget 2016, 7, 4712-4723. [CrossRef] [PubMed]

77. Peng, Y.; Meng, K.; Jiang, L.; Zhong, Y.; Yang, Y.; Lan, Y.; Zeng, Q.; Cheng, L. Thymic stromal lymphopoietin-induced HOTAIR activation promotes endothelial cell proliferation and migration in atherosclerosis. Biosci. Rep. 2017, 37, BSR20170351. [CrossRef]

78. Shan, K.; Jiang, Q.; Wang, X.-Q.; Wang, Y.-N.-Z.; Yang, H.; Yao, M.-D.; Liu, C.; Li, X.-M.; Yao, J.; Liu, B.; et al. Role of long non-coding RNA-RNCR3 in atherosclerosis-related vascular dysfunction. Cell Death Dis. 2016, 7, e2248. [CrossRef]

79. Shan, K.; Li, C.-P.; Liu, C.; Liu, X.; Yan, B. RNCR3: A regulator of diabetes mellitus-related retinal microvascular dysfunction. Biochem. Biophys. Res. Commun. 2017, 482, 777-783. [CrossRef]

80. Xu, X.; Ma, C.; Liu, C.; Duan, Z.; Zhang, L. Knockdown of long noncoding RNA XIST alleviates oxidative low-density lipoprotein-mediated endothelial cells injury through modulation of miR-320/NOD2 axis. Biochem. Biophys. Res. Commun. 2018, 503, 586-592. [CrossRef]

81. Jia, P.; Cai, H.; Liu, X.; Chen, J.; Ma, J.; Wang, P.; Liu, Y.; Zheng, J.; Xue, Y. Long non-coding RNA H19 regulates glioma angiogenesis and the biological behavior of glioma-associated endothelial cells by inhibiting microRNA-29a. Cancer Lett. 2016, 381, 359-369. [CrossRef] [PubMed]

82. Weirick, T.; Militello, G.; Uchida, S. Long non-coding RNAs in endothelial biology. Front. Physiol. 2018, 9, 522. [CrossRef] [PubMed]

83. Li, Z.; Li, J.; Tang, N. Long noncoding RNA Malat1 is a potent autophagy inducer protecting brain microvascular endothelial cells against oxygen-glucose deprivation/reoxygenation-induced injury by sponging miR-26b and upregulating ULK2 expression. Neuroscience 2017, 354, 1-10. [CrossRef] [PubMed]

84. Sun, J.-Y.; Zhao, Z.-W.; Li, W.-M.; Yang, G.; Jing, P.-Y.; Li, P.; Dang, H.-Z.; Chen, Z.; Zhou, Y.-A.; Li, X.-F. Knockdown of MALAT1 expression inhibits HUVEC proliferation by upregulation of miR-320a and downregulation of FOXM1 expression. Oncotarget 2017, 8, 61499-61509. [CrossRef] [PubMed]

85. Cabili, M.N.; Trapnell, C.; Goff, L.; Koziol, M.; Tazon-Vega, B.; Regev, A.; Rinn, J.L. Integrative annotation of human large intergenic noncoding RNAs reveals global properties and specific subclasses. Genes Dev. 2011, 25, 1915-1927. [CrossRef] [PubMed]

86. Kashi, K.; Henderson, L.; Bonetti, A.; Carninci, P. Discovery and functional analysis of lncRNAs: Methodologies to investigate an uncharacterized transcriptome. Biochim. Biophys. Acta 2016, 1859, 3-15. [CrossRef]

87. Derrien, T.; Johnson, R.; Bussotti, G.; Tanzer, A.; Djebali, S.; Tilgner, H.; Guernec, G.; Martín, D.; Merkel, A.; Knowles, D.G.; et al. The GENCODE v7 catalog of human long noncoding RNAs: Analysis of their gene structure, evolution, and expression. Genome Res. 2012, 22, 1775-1789. [CrossRef]

88. Mockler, T.C.; Ecker, J.R. Applications of DNA tiling arrays for whole-genome analysis. Genomics 2005, 85, 1-15. [CrossRef]

89. Yazaki, J.; Gregory, B.D.; Ecker, J.R. Mapping the genome landscape using tiling array technology. Curr. Opin. Plant Biol. 2007, 10, 534-542. [CrossRef]

90. Lowe, R.; Shirley, N.; Bleackley, M.; Dolan, S.; Shafee, T. Transcriptomics technologies. PLoS Comput. Biol. 2017, 13, e1005457. [CrossRef]

91. Hu, M.; Polyak, K. Serial analysis of gene expression. Nat. Protoc. 2006, 1, 1743-1760. [CrossRef] [PubMed]

92. Takahashi, H.; Lassmann, T.; Murata, M.; Carninci, P. 5' end-centered expression profiling using cap-analysis gene expression and next-generation sequencing. Nat. Protoc. 2012, 7, 542-561. [CrossRef] [PubMed]

93. Shiraki, T.; Kondo, S.; Katayama, S.; Waki, K.; Kasukawa, T.; Kawaji, H.; Kodzius, R.; Watahiki, A.; Nakamura, M.; Arakawa, T.; et al. Cap analysis gene expression for high-throughput analysis of transcriptional starting point and identification of promoter usage. Proc. Natl. Acad. Sci. USA 2003, 100, 15776-15781. [CrossRef] [PubMed] 
94. Kurosawa, J.; Nishiyori, H.; Hayashizaki, Y. Deep cap analysis of gene expression. In PCR Protocols; Springer: Berlin/Heidelberg, Germany, 2011; pp. 147-163.

95. Takahashi, H.; Kato, S.; Murata, M.; Carninci, P. CAGE (cap analysis of gene expression): A protocol for the detection of promoter and transcriptional networks. In Gene Regulatory Networks; Springer: Berlin/Heidelberg, Germany, 2012; pp. 181-200.

96. Kawaji, H.; Lizio, M.; Itoh, M.; Kanamori-Katayama, M.; Kaiho, A.; Nishiyori-Sueki, H.; Shin, J.W.; Kojima-Ishiyama, M.; Kawano, M.; Murata, M.; et al. Comparison of CAGE and RNA-seq transcriptome profiling using clonally amplified and single-molecule next-generation sequencing. Genome Res. 2014, 24, 708-717. [CrossRef] [PubMed]

97. Wang, Z.; Gerstein, M.; Snyder, M. RNA-Seq: A revolutionary tool for transcriptomics. Nat. Rev. Genet. 2009, 10, 57-63. [CrossRef] [PubMed]

98. Quinn, E.M.; Cormican, P.; Kenny, E.M.; Hill, M.; Anney, R.; Gill, M.; Corvin, A.P.; Morris, D.W. Development of strategies for SNP detection in RNA-seq data: Application to lymphoblastoid cell lines and evaluation using 1000 Genomes data. PLoS ONE 2013, 8, e58815. [CrossRef]

99. Ozsolak, F.; Milos, P.M. RNA sequencing: Advances, challenges and opportunities. Nat. Rev. Genet. 2011, 12, 87-98. [CrossRef]

100. Rinn, J.L.; Kertesz, M.; Wang, J.K.; Squazzo, S.L.; Xu, X.; Brugmann, S.A.; Goodnough, H.; Helms, J.A.; Farnham, P.J.; Segal, E.; et al. Functional demarcation of active and silent chromatin domains in human HOX loci by noncoding RNAs. Cell 2007, 129, 1311-1323. [CrossRef]

101. Laubinger, S.; Zeller, G.; Henz, S.R.; Sachsenberg, T.; Widmer, C.K.; Naouar, N.; Vuylsteke, M.; Schölkopf, B.; Rätsch, G.; Weigel, D. At-TAX: A whole genome tiling array resource for developmental expression analysis and transcript identification in Arabidopsis thaliana. Genome Biol. 2008, 9, R112. [CrossRef]

102. Gibb, E.A.; Vucic, E.A.; Enfield, K.S.S.; Stewart, G.L.; Lonergan, K.M.; Kennett, J.Y.; Becker-Santos, D.D.; Macaulay, C.E.; Lam, S.; Brown, C.J.; et al. Human cancer long non-coding RNA transcriptomes. PLoS ONE 2011, 6, e25915. [CrossRef]

103. Kodzius, R.; Kojima, M.; Nishiyori, H.; Nakamura, M.; Fukuda, S.; Tagami, M.; Sasaki, D.; Imamura, K.; Kai, C.; Harbers, M.; et al. CAGE: Cap analysis of gene expression. Nat. Methods 2006, 3, 211-222. [CrossRef] [PubMed]

104. Hon, C.-C.; Ramilowski, J.A.; Harshbarger, J.; Bertin, N.; Rackham, O.J.L.; Gough, J.; Denisenko, E.; Schmeier, S.; Poulsen, T.M.; Severin, J.; et al. An atlas of human long non-coding RNAs with accurate $5^{\prime}$ ends. Nature 2017, 543, 199-204. [CrossRef] [PubMed]

105. Lasda, E.; Parker, R. Circular RNAs: Diversity of form and function. RNA 2014, 20, 1829-1842. [CrossRef] [PubMed]

106. Bai, Y.; Kinne, J.; Donham, B.; Jiang, F.; Ding, L.; Hassler, J.R.; Kaufman, R.J. Read-Split-Run: An improved bioinformatics pipeline for identification of genome-wide non-canonical spliced regions using RNA-Seq data. BMC Genom. 2016, 17, 503. [CrossRef] [PubMed]

107. Pan, Q.; Shai, O.; Lee, L.J.; Frey, B.J.; Blencowe, B.J. Deep surveying of alternative splicing complexity in the human transcriptome by high-throughput sequencing. Nat. Genet. 2008, 40, 1413-1415. [CrossRef] [PubMed]

108. Holt, R.A.; Jones, S.J. The new paradigm of flow cell sequencing. Genome Res. 2008, 18, 839-846. [CrossRef] [PubMed]

109. Cloonan, N.; Forrest, A.R.R.; Kolle, G.; A Gardiner, B.B.; Faulkner, G.J.; Brown, M.K.; Taylor, D.F.; Steptoe, A.L.; Wani, S.; Bethel, G.; et al. Stem cell transcriptome profiling via massive-scale mRNA sequencing. Nat. Methods 2008, 5, 613-619. [CrossRef]

110. McFadden, E.J.; Hargrove, A.E. Biochemical methods to investigate lncRNA and the influence of lncRNA: Protein complexes on chromatin. Biochemistry 2016, 55, 1615-1630. [CrossRef]

111. Huarte, M. The emerging role of lncRNAs in cancer. Nat. Med. 2015, 21, 1253-1261. [CrossRef]

112. Chang, K.; Marran, K.; Valentine, A.; Hannon, G.J. RNAi in cultured mammalian cells using synthetic siRNAs. Cold Spring Harb. Protoc. 2012, 2012, 957-961. [CrossRef]

113. Rao, D.D.; Vorhies, J.S.; Senzer, N.; Nemunaitis, J. siRNA vs. shRNA: Similarities and differences. Adv. Drug Deliv. Rev. 2009, 61, 746-759. [CrossRef] [PubMed]

114. Sledz, C.A.; Williams, B.R.G. RNA interference in biology and disease. Blood 2005, 106, 787-794. [CrossRef] [PubMed] 
115. Luo, K.Q.; Chang, D.C. The gene-silencing efficiency of siRNA is strongly dependent on the local structure of mRNA at the targeted region. Biochem. Biophys. Res. Commun. 2004, 318, 303-310. [CrossRef] [PubMed]

116. Kole, R.; Krainer, A.R.; Altman, S. RNA therapeutics: Beyond RNA interference and antisense oligonucleotides. Nat. Rev. Drug Discov. 2012, 11, 125-140. [CrossRef] [PubMed]

117. Ward, A.J.; Norrbom, M.; Chun, S.; Bennett, C.F.; Rigo, F. Nonsense-mediated decay as a terminating mechanism for antisense oligonucleotides. Nucleic Acids Res. 2014, 42, 5871-5879. [CrossRef] [PubMed]

118. Dias, N.; Stein, C. Antisense oligonucleotides: Basic concepts and mechanisms. Mol. Cancer Ther. 2002, 1, 347-355. [PubMed]

119. Lennox, K.A.; Behlke, M.A. Cellular localization of long non-coding RNAs affects silencing by RNAi more than by antisense oligonucleotides. Nucleic Acids Res. 2015, 44, 863-877. [CrossRef]

120. Ho, T.-T.; Zhou, N.; Huang, J.; Koirala, P.; Xu, M.; Fung, R.; Wu, F.; Mo, Y.-Y. Targeting non-coding RNAs with the CRISPR/Cas9 system in human cell lines. Nucleic Acids Res. 2014, 43, e17. [CrossRef]

121. Cong, L.; Ran, F.A.; Cox, D.; Lin, S.; Barretto, R.; Habib, N.; Hsu, P.D.; Wu, X.; Jiang, W.; Marraffini, L.A.; et al. Multiplex genome engineering using CRISPR/Cas systems. Science 2013, 339, 819-823. [CrossRef]

122. Bassett, A.R.; Akhtar, A.; Barlow, D.P.; Bird, A.P.; Brockdorff, N.; Duboule, D.; Ephrussi, A.; Ferguson-Smith, A.C.; Gingeras, T.R.; Haerty, W.; et al. Science Forum: Considerations when investigating lncRNA function in vivo. eLife 2014, 3, e03058. [CrossRef]

123. Liu, Z.; Hui, Y.; Shi, L.; Chen, Z.; Xu, X.; Chi, L.; Fan, B.; Fang, Y.; Liu, Y.; Ma, L.; et al. Efficient CRISPR/Cas9-mediated versatile, predictable, and donor-free gene knockout in human pluripotent stem cells. Stem Cell Rep. 2016, 7, 496-507. [CrossRef] [PubMed]

124. Liu, Y.; Han, X.; Yuan, J.; Geng, T.; Chen, S.; Hu, X.; Cui, I.H.; Cui, H. Biallelic Insertion of a Transcriptional Terminator via CRISPR/Cas9 Efficiently Silences Expression of Protein-coding and Non-coding RNA Genes. J. Biol. Chem. 2017, 292, 5624-5633. [CrossRef] [PubMed]

125. Ghosh, S.; Tibbit, C.; Liu, J.-L. Effective knockdown of Drosophila long non-coding RNAs by CRISPR interference. Nucleic Acids Res. 2016, 44, e84. [CrossRef] [PubMed]

126. Liu, S.J.; Horlbeck, M.A.; Cho, S.W.; Birk, H.S.; Malatesta, M.; He, D.; Attenello, F.J.; Villalta, J.E.; Cho, M.Y.; Chen, Y.; et al. CRISPRi-based genome-scale identification of functional long noncoding RNA loci in human cells. Science 2017, 355, eaah7111. [CrossRef] [PubMed]

127. Guttman, M.; Donaghey, J.; Carey, B.W.; Garber, M.; Grenier, J.K.; Munson, G.; Young, G.; Lucas, A.B.; Ach, R.; Bruhn, L.; et al. lincRNAs act in the circuitry controlling pluripotency and differentiation. Nature 2011, 477, 295-300. [CrossRef] [PubMed]

128. Watts, J.K.; Corey, D.R. Silencing disease genes in the laboratory and the clinic. J. Pathol. 2012, 226, 365-379. [CrossRef] [PubMed]

129. Stojic, L.; Niemczyk, M.; Orjalo, A.; Ito, Y.; Ruijter, A.E.M.; Uribe-Lewis, S.; Joseph, N.; Weston, S.; Menon, S.; Odom, D.T.; et al. Transcriptional silencing of long noncoding RNA GNG12-AS1 uncouples its transcriptional and product-related functions. Nat. Commun. 2016, 7, 10406. [CrossRef] [PubMed]

130. Bennett, C.F.; Swayze, E.E. RNA targeting therapeutics: Molecular mechanisms of antisense oligonucleotides as a therapeutic platform. Annu. Rev. Pharmacol. Toxicol. 2010, 50, 259-293. [CrossRef]

131. Wiedenheft, B.; Sternberg, S.H.; Doudna, J.A. RNA-guided genetic silencing systems in bacteria and archaea. Nature 2012, 482, 331-338. [CrossRef]

132. Han, J.; Zhang, J.; Chen, L.; Shen, B.; Zhou, J.; Hu, B.; Du, Y.; Tate, P.H.; Huang, X.; Zhang, W. Efficient in vivo deletion of a large imprinted lncRNA by CRISPR/Cas9. RNA Biol. 2014, 11, 829-835. [CrossRef]

133. Eißmann, M.; Gutschner, T.; Hämmerle, M.; Günther, S.; Caudron-Herger, M.; Groß, M.; Schirmacher, P.; Rippe, K.; Braun, T.; Diederichs, S.; et al. Loss of the abundant nuclear non-coding RNA MALAT1 is compatible with life and development. RNA Biol. 2012, 9, 1076-1087. [CrossRef] [PubMed]

134. Konermann, S.; Brigham, M.D.; Trevino, A.E.; Joung, J.; Abudayyeh, O.O.; Barcena, C.; Hsu, P.D.; Habib, N.; Gootenberg, J.S.; Nishimasu, H.; et al. Genome-scale transcriptional activation by an engineered CRISPR-Cas9 complex. Nature 2015, 517, 583-588. [CrossRef] [PubMed]

135. Xiang, J.-F.; Yin, Q.-F.; Chen, T.; Zhang, Y.; Zhang, X.-O.; Wu, Z.; Zhang, S.; Wang, H.-B.; Ge, J.; Lu, X.; et al. Human colorectal cancer-specific CCAT1-L lncRNA regulates long-range chromatin interactions at the MYC locus. Cell Res. 2014, 24, 513-531. [CrossRef] [PubMed] 
136. Yang, H.; Wang, H.; Shivalila, C.S.; Cheng, A.W.; Shi, L.; Jaenisch, R. One-step generation of mice carrying reporter and conditional alleles by CRISPR/Cas-mediated genome engineering. Cell 2013, 154, 1370-1379. [CrossRef] [PubMed]

137. Dominguez, A.A.; Lim, W.A.; Qi, L.S. Beyond editing: Repurposing CRISPR-Cas9 for precision genome regulation and interrogation. Nat. Rev. Mol. Cell Biol. 2016, 17, 5-15. [CrossRef] [PubMed]

138. Gilbert, L.A.; Larson, M.H.; Morsut, L.; Liu, Z.; Brar, G.A.; Torres, S.E.; Stern-Ginossar, N.; Brandman, O.; Whitehead, E.H.; Doudna, J.A.; et al. CRISPR-mediated modular RNA-guided regulation of transcription in eukaryotes. Cell 2013, 154, 442-451. [CrossRef]

139. Gilbert, L.A.; Horlbeck, M.A.; Adamson, B.; Villalta, J.E.; Chen, Y.; Whitehead, E.H.; Guimarães, C.; Panning, B.; Ploegh, H.L.; Bassik, M.C.; et al. Genome-scale CRISPR-mediated control of gene repression and activation. Cell 2014, 159, 647-661. [CrossRef] [PubMed]

140. Qi, L.S.; Larson, M.H.; Gilbert, L.A.; Doudna, J.A.; Weissman, J.S.; Arkin, A.P.; Lim, W.A. Repurposing CRISPR as an RNA-guided platform for sequence-specific control of gene expression. Cell 2013, 152, 1173-1183. [CrossRef] [PubMed]

141. Nishimasu, H.; Cong, L.; Yan, W.X.; Ran, F.A.; Zetsche, B.; Li, Y.; Kurabayashi, A.; Ishitani, R.; Zhang, F.; Nureki, O. Crystal structure of Staphylococcus aureus Cas9. Cell 2015, 162, 1113-1126. [CrossRef] [PubMed]

142. Li, W.; Notani, D.; Ma, Q.; Tanasa, B.; Nunez, E.; Chen, A.Y.; Merkurjev, D.; Zhang, J.; Ohgi, K.; Song, X.; et al. Functional roles of enhancer RNAs for oestrogen-dependent transcriptional activation. Nature 2013, 498, 516-520. [CrossRef] [PubMed]

143. Ørom, U.A.; Derrien, T.; Beringer, M.; Gumireddy, K.; Gardini, A.; Bussotti, G.; Lai, F.; Zytnicki, M.; Notredame, C.; Huang, Q.; et al. Long noncoding RNAs with enhancer-like function in human cells. Cell 2010, 143, 46-58. [CrossRef] [PubMed]

144. Kornienko, A.E.; Guenzl, P.M.; Barlow, D.P.; Pauler, F.M. Gene regulation by the act of long non-coding RNA transcription. BMC Biol. 2013, 11, 59. [CrossRef] [PubMed]

145. Carlevaro-Fita, J.; Johnson, R. Global positioning system: Understanding long noncoding RNAs through subcellular localization. Mol. Cell 2019, 73, 869-883. [CrossRef] [PubMed]

146. Carlevaro-Fita, J.; Rahim, A.; Guigó, R.; Vardy, L.A.; Johnson, R. Cytoplasmic long noncoding RNAs are frequently bound to and degraded at ribosomes in human cells. RNA 2016, 22, 867-882. [CrossRef] [PubMed]

147. Rashid, F.; Shah, A.; Shan, G. Long non-coding RNAs in the cytoplasm. Genom. Proteom. Bioinform. 2016, 14, 73-80. [CrossRef] [PubMed]

148. Sun, Q.; Hao, Q.; Prasanth, K.V. Nuclear long noncoding RNAs: Key regulators of gene expression. Trends Genet. 2018, 34, 142-157. [CrossRef] [PubMed]

149. Raj, A.; Bogaard, P.V.D.; Rifkin, S.A.; Van Oudenaarden, A.; Tyagi, S. Imaging individual mRNA molecules using multiple singly labeled probes. Nat. Methods 2008, 5, 877-879. [CrossRef]

150. Dunagin, M.; Cabili, M.N.; Rinn, J.; Raj, A. Visualization of lncRNA by single-molecule fluorescence in situ hybridization. In Nuclear Bodies and Noncoding RNAs; Springer: Berlin/Heidelberg, Germany, 2015; pp. 3-19.

151. Vance, K.W. Mapping long noncoding RNA chromatin occupancy using capture hybridization analysis of RNA targets (CHART). In Enhancer RNAs; Springer: Berlin/Heidelberg, Germany, 2017; pp. 39-50.

152. Sexton, A.N.; Machyna, M.; Simon, M.D. Capture hybridization analysis of DNA targets. In Polycomb Group Proteins; Springer: Berlin/Heidelberg, Germany, 2016; pp. 87-97.

153. Chu, C.; Quinn, J.; Chang, H.Y. Chromatin isolation by RNA purification (ChIRP). J. Vis. Exp. JoVE 2012, 61, e3912. [CrossRef]

154. Faoro, C.; Ataide, S.F. Ribonomic approaches to study the RNA-binding proteome. FEBS Lett. 2014, 588, 3649-3664. [CrossRef]

155. Chu, C.; Qu, K.; Zhong, F.L.; Artandi, S.E.; Chang, H.Y. Genomic maps of long noncoding RNA occupancy reveal principles of RNA-chromatin interactions. Mol. Cell 2011, 44, 667-678. [CrossRef] [PubMed]

156. Engreitz, J.; Lander, E.S.; Guttman, M. RNA antisense purification (RAP) for mapping RNA interactions with chromatin. Methods Mol. Biol. (Clifton NJ) 2015, 1262, 183-197.

157. Engreitz, J.M.; Pandya-Jones, A.; McDonel, P.; Shishkin, A.; Sirokman, K.; Surka, C.; Kadri, S.; Xing, J.; Goren, A.; Lander, E.S.; et al. The Xist lncRNA exploits three-dimensional genome architecture to spread across the X chromosome. Science 2013, 341, 1237973. [CrossRef] [PubMed] 
158. Engreitz, J.M.; Sirokman, K.; McDonel, P.; Shishkin, A.A.; Surka, C.; Russell, P.; Grossman, S.R.; Chow, A.Y.; Guttman, M.; Lander, E.S. RNA-RNA interactions enable specific targeting of noncoding RNAs to nascent Pre-mRNAs and chromatin sites. Cell 2014, 159, 188-199. [CrossRef]

159. Helwak, A.; Kudla, G.; Dudnakova, T.; Tollervey, D. Mapping the human miRNA interactome by CLASH reveals frequent noncanonical binding. Cell 2013, 153, 654-665. [CrossRef] [PubMed]

160. Kudla, G.; Granneman, S.; Hahn, D.; Beggs, J.D.; Tollervey, D. Cross-linking, ligation, and sequencing of hybrids reveals RNA-RNA interactions in yeast. Proc. Natl. Acad. Sci. USA 2011, 108, 10010-10015. [CrossRef] [PubMed]

161. Hausser, J.; Zavolan, M. Identification and consequences of miRNA-target interactions-beyond repression of gene expression. Nat. Rev. Genet. 2014, 15, 599-612. [CrossRef] [PubMed]

162. Lu, Z.; Zhang, Q.C.; Lee, B.; Flynn, R.A.; Smith, M.A.; Robinson, J.T.; Davidovich, C.; Gooding, A.R.; Goodrich, K.J.; Mattick, J.S.; et al. RNA Duplex Map in Living Cells Reveals Higher-Order Transcriptome Structure. Cell 2016, 165, 1267-1279. [CrossRef] [PubMed]

163. Gagliardi, M.; Matarazzo, M.R. RIP: RNA Immunoprecipitation. Methods Mol. Biol. (Clifton NJ) 2016, 1480, 73-86.

164. Zhao, J.; Ohsumi, T.K.; Kung, J.T.; Ogawa, Y.; Grau, D.J.; Sarma, K.; Song, J.J.; Kingston, R.E.; Borowsky, M.; Lee, J.T. Genome-wide identification of polycomb-associated RNAs by RIP-seq. Mol. Cell 2010, 40, 939-953. [CrossRef]

165. Selth, L.A.; Close, P.; Svejstrup, J.Q. Studying RNA-protein interactions in vivo by RNA immunoprecipitation. Methods Mol. Biol. (Clifton NJ) 2011, 791, 253-264.

166. Niranjanakumari, S.; Lasda, E.; Brazas, R.; Garcia-Blanco, M.A. Reversible cross-linking combined with immunoprecipitation to study RNA-protein interactions in vivo. Methods (San Diego California) 2002, 26, 182-190. [CrossRef]

167. Guil, S.; Soler, M.; Portela, A.; Carrère, J.; Fonalleras, E.; Gómez, A.; Villanueva, A.; Esteller, M.; Moruno, A.G. Intronic RNAs mediate EZH2 regulation of epigenetic targets. Nat. Struct. Mol. Biol. 2012, 19, 664-670. [CrossRef] [PubMed]

168. Licatalosi, D.D.; Mele, A.; Fak, J.J.; Ule, J.; Kayikci, M.; Chi, S.W.; Clark, T.A.; Schweitzer, A.C.; Blume, J.E.; Wang, X.; et al. HITS-CLIP yields genome-wide insights into brain alternative RNA processing. Nature 2008, 456, 464-469. [CrossRef] [PubMed]

169. Chi, S.W.; Zang, J.B.; Mele, A.; Darnell, R.B. Argonaute HITS-CLIP decodes microRNA-mRNA interaction maps. Nature 2009, 460, 479-486. [CrossRef] [PubMed]

170. Zhang, C.; Darnell, R.B. Mapping in vivo protein-RNA interactions at single-nucleotide resolution from HITS-CLIP data. Nat. Biotechnol. 2011, 29, 607-614. [CrossRef] [PubMed]

171. Spitzer, J.; Hafner, M.; Landthaler, M.; Ascano, M.; Farazi, T.; Wardle, G.; Nusbaum, J.; Khorshid, M.; Burger, L.; Zavolan, M.; et al. PAR-CLIP (Photoactivatable Ribonucleoside-Enhanced Crosslinking and Immunoprecipitation): A step-by-step protocol to the transcriptome-wide identification of binding sites of RNA-binding proteins. Methods Enzymol. 2014, 539, 113-161. [PubMed]

172. Hafner, M.; Landthaler, M.; Burger, L.; Khorshid, M.; Hausser, J.; Berninger, P.; Rothballer, A.; Ascano, M.; Jungkamp, A.C.; Munschauer, M.; et al. PAR-CliP—A method to identify transcriptome-wide the binding sites of RNA binding proteins. J. Vis. Exp. JoVE 2010, 41, e2034. [CrossRef]

173. Ascano, M.; Hafner, M.; Cekan, P.; Gerstberger, S.; Tuschl, T. Identification of RNA-protein interaction networks using PAR-CLIP. Wiley Interdiscip. Rev. RNA 2012, 3, 159-177. [CrossRef]

174. Fok, E.T.; Scholefield, J.; Fanucchi, S.; Mhlanga, M.M. The emerging molecular biology toolbox for the study of long noncoding RNA biology. Epigenomics 2017, 9, 1317-1327. [CrossRef]

175. Shukla, C.J.; McCorkindale, A.L.; Gerhardinger, C.; Korthauer, K.D.; Cabili, M.N.; Shechner, D.M.; Irizarry, R.A.; Maass, P.G.; Rinn, J.L. High-throughput identification of RNA nuclear enrichment sequences. EMBO J. 2018, 37, e98452. [CrossRef] [PubMed]

176. Vance, K.W.; Ponting, C.P. Transcriptional regulatory functions of nuclear long noncoding RNAs. Trends Genet. 2014, 30, 348-355. [CrossRef] [PubMed]

177. Zhao, J.; Sun, B.K.; Erwin, J.A.; Song, J.-J.; Lee, J.T. Polycomb proteins targeted by a short repeat RNA to the mouse $X$ chromosome. Science 2008, 322, 750-756. [CrossRef] [PubMed]

178. Karamysheva, A. Mechanisms of angiogenesis. Biochemistry (Moscow) 2008, 73, 751. [CrossRef] [PubMed]

179. Carmeliet, P. Angiogenesis in health and disease. Nat. Med. 2003, 9, 653-660. [CrossRef] [PubMed] 
180. LaGory, E.L.; Giaccia, A.J. The ever-expanding role of HIF in tumour and stromal biology. Nat. Cell Biol. 2016, 18, 356-365. [CrossRef]

181. Muz, B.; De La Puente, P.; Azab, F.; Azab, A.K. The role of hypoxia in cancer progression, angiogenesis, metastasis, and resistance to therapy. Hypoxia 2015, 3, 83-92. [CrossRef]

182. Cuadrado-Godia, E.; Regueiro, A.; Núñez, J.; Díaz-Ricard, M.; Novella, S.; Oliveras, A.; Valverde, M.A.; Marrugat, J.; Ois, Á.; Giralt-Steinhauer, E.; et al. Endothelial progenitor cells predict cardiovascular events after atherothrombotic stroke and acute myocardial infarction. A PROCELL Substudy. PLoS ONE 2015, 10, e0132415. [CrossRef]

183. Ali, M.A.; Elsayed, A.S.; Ali, M.M.; Shafei, A.E.S.; Ghanem, H.G.; I Shehata, A.; Abdelgawad, A.A.; Handal, H.R.; Talaat, K.A.; Ashaal, A.E.; et al. Mechanistic effects of mesenchymal and hematopoietic stem cells: New therapeutic targets in myocardial infarction. J. Cell. Biochem. 2018, 119, 5274-5286.

184. Ferrara, N.; Kerbel, R.S. Angiogenesis as a therapeutic target. Nature 2005, 438, 967-974. [CrossRef]

185. M Kumar, M.; Goyal, R. lncRNA as a therapeutic target for angiogenesis. Curr. Top. Med. Chem. 2017, 17, 1750-1757. [CrossRef] [PubMed]

186. Zhao, M.; Wang, J.; Xi, X.; Tan, N.; Zhang, L. SNHG12 Promotes Angiogenesis Following Ischemic Stroke via Regulating miR-150/VEGF Pathway. Neuroscience 2018, 390, 231-240. [CrossRef] [PubMed]

187. Lin, J.; Cao, S.; Wang, Y.; Hu, Y.; Liu, H.; Li, J.; Chen, J.; Li, P.; Liu, J.; Wang, Q.; et al. Long noncoding RNA UBE2CP3 enhances HCC cell secretion of VEGFA and promotes angiogenesis by activating ERK1/2/HIF-1 $\alpha /$ VEGFA signalling in hepatocellular carcinoma. J. Exp. Clin. Cancer Res. 2018, 37, 113. [CrossRef] [PubMed]

188. Teng, W.; Qiu, C.; He, Z.; Wang, G.; Xue, Y.; Hui, X. Linc00152 suppresses apoptosis and promotes migration by sponging miR-4767 in vascular endothelial cells. Oncotarget 2017, 8, 85014-85023. [CrossRef] [PubMed]

189. Yin, D.; Fu, C.; Sun, D. Silence of lncRNA UCA1 Represses the Growth and Tube Formation of Human Microvascular Endothelial Cells Through miR-195. Cell. Physiol. Biochem. 2018, 49, 1499-1511. [CrossRef] [PubMed]

190. Zhao, X.; Liu, Y.; Li, Z.; Zheng, S.; Wang, Z.; Li, W.; Bi, Z.; Li, L.; Jiang, Y.; Luo, Y.; et al. Linc00511 acts as a competing endogenous RNA to regulate VEGFA expression through sponging hsa-miR-29b-3p in pancreatic ductal adenocarcinoma. J. Cell. Mol. Med. 2018, 22, 655-667. [CrossRef]

191. Ma, Y.; Xue, Y.; Liu, X.; Qu, C.; Cai, H.; Wang, P.; Li, Z. SNHG15 affects the growth of glioma microvascular endothelial cells by negatively regulating miR-153. Oncol. Rep. 2017, 38, 3265-3277. [CrossRef] [PubMed]

192. Castellano, J.J.; Navarro, A.; Viñolas, N.; Marrades, R.M.; Moises, J.; Cordeiro, A.; Saco, A.; Muñoz, C.; Fuster, D.; Molins, L.; et al. LincRNA-p21 Impacts Prognosis in Resected Non-Small Cell Lung Cancer Patients through Angiogenesis Regulation. J. Thorac. Oncol. 2016, 11, 2173-2182. [CrossRef]

193. Bao, M.H.; Li, G.Y.; Huang, X.S.; Tang, L.; Dong, L.P.; Li, J.M. Long non-coding RNA LINC00657 acting as miR-590-3p sponge to facilitate low concentration oxidized low-density lipoprotein-induced angiogenesis. Mol. Pharmacol. 2018, 93, 368-375. [CrossRef]

194. Young, T.; Matsuda, T.; Cepko, C. The noncoding RNA taurine upregulated gene 1 is required for differentiation of the murine retina. Curr. Biol. 2005, 15, 501-512. [CrossRef]

195. Czauderna, P.; Lopez-Terrada, D.; Hiyama, E.; Häberle, B.; Malogolowkin, M.H.; Meyers, R.L. Hepatoblastoma state of the art: Pathology, genetics, risk stratification, and chemotherapy. Curr. Opin. Pediatr. 2014, 26, 19-28. [CrossRef] [PubMed]

196. Dong, R.; Jia, D.; Xue, P.; Cui, X.; Li, K.; Zheng, S.; He, X.; Dong, K. Genome-wide analysis of long noncoding RNA (lncRNA) expression in hepatoblastoma tissues. PLoS ONE 2014, 9, e85599. [CrossRef] [PubMed]

197. Zhou, Y.; Zhang, X.; Klibanski, A. MEG3 non-coding RNA: A tumor suppressor. J. Mol. Endocrinol. 2012, 48, 45-53. [CrossRef] [PubMed]

198. Zheng, Y.; Ley, S.H.; Hu, F.B. Global aetiology and epidemiology of type 2 diabetes mellitus and its complications. Nat. Rev. Endocrinol. 2018, 14, 88-98. [CrossRef] [PubMed]

199. Mellbin, L.G.; Anselmino, M.; Lars, R. Diabetes, prediabetes and cardiovascular risk. Eur. J. Cardiovasc. Prev. Rehabil. 2010, 17, s9-s14. [CrossRef] [PubMed]

200. Low Wang, C.C.; Hess, C.N.; Hiatt, W.R.; Goldfine, A.B. Clinical update: Cardiovascular disease in diabetes mellitus: Atherosclerotic cardiovascular disease and heart failure in type 2 diabetes mellitus-mechanisms, management, and clinical considerations. Circulation 2016, 133, 2459-2502. [CrossRef] 
201. Roberts, A.C.; Porter, K.E. Cellular and molecular mechanisms of endothelial dysfunction in diabetes. Diabetes Vasc. Dis. Res. 2013, 10, 472-482. [CrossRef]

202. Hamdy, O.; Ledbury, S.; Mullooly, C.; Jarema, C.; Porter, S.; Ovalle, K.; Moussa, A.; Caselli, A.; Caballero, A.E.; Economides, P.A.; et al. Lifestyle modification improves endothelial function in obese subjects with the insulin resistance syndrome. Diabetes Care 2003, 26, 2119-2125. [CrossRef]

203. Hamburg, N.M.; Larson, M.G.; Vita, J.A.; Vasan, R.S.; Keyes, M.J.; Widlansky, M.E.; Fox, C.S.; Mitchell, G.F.; Levy, D.; Meigs, J.B.; et al. Metabolic syndrome, insulin resistance, and brachial artery vasodilator function in Framingham Offspring participants without clinical evidence of cardiovascular disease. Am. J. Cardiol. 2008, 101, 82-88. [CrossRef]

204. Avogaro, A.; De Kreutzenberg, S.V.; Fadini, G.P. Endothelial dysfunction: Causes and consequences in patients with diabetes mellitus. Diabetes Res. Clin. Pract. 2008, 82, S94-S101. [CrossRef]

205. Soldatos, G.; Cooper, M.E.; Jandeleit-Dahm, K.A.M. Advanced-glycation end products in insulin-resistant states. Curr. Hypertens. Rep. 2005, 7, 96-102. [CrossRef] [PubMed]

206. Tabit, C.E.; Chung, W.B.; Hamburg, N.M.; Vita, J.A. Endothelial dysfunction in diabetes mellitus: Molecular mechanisms and clinical implications. Rev. Endocr. Metab. Disord. 2010, 11, 61-74. [CrossRef]

207. He, X.; Ou, C.; Xiao, Y.; Han, Q.; Li, H.; Zhou, S. lncRNAs: Key players and novel insights into diabetes mellitus. Oncotarget 2017, 8, 71325-71341. [CrossRef] [PubMed]

208. Singh, K.K.; Mantella, L.-E.; Pan, Y.; Quan, A.; Sabongui, S.; Sandhu, P.; Teoh, H.; Al-Omran, M.; Verma, S. A global profile of glucose-sensitive endothelial-expressed long non-coding RNAs. Can. J. Physiol. Pharmacol. 2016, 94, 1007-1014. [CrossRef]

209. Yan, B.; Yao, J.; Liu, J.Y.; Li, X.M.; Wang, X.Q.; Li, Y.J.; Tao, Z.F.; Song, Y.C.; Chen, Q.; Jiang, Q. IncRNA-MIAT regulates microvascular dysfunction by functioning as a competing endogenous RNA. Circ. Res. 2015, 116, 1143-1156. [CrossRef]

210. Widder, J.D.; Fraccarollo, D.; Galuppo, P.; Hansen, J.M.; Jones, D.P.; Ertl, G.; Bauersachs, J. Attenuation of angiotensin II-induced vascular dysfunction and hypertension by overexpression of thioredoxin 2 . Hypertension 2009, 54, 338-344. [CrossRef]

211. Doughan, A.K.; Harrison, D.G.; Dikalov, S.I. Molecular mechanisms of angiotensin II-mediated mitochondrial dysfunction: Linking mitochondrial oxidative damage and vascular endothelial dysfunction. Circ. Res. 2008, 102, 488-496. [CrossRef] [PubMed]

212. Vecchione, C.; Carnevale, D.; Di Pardo, A.; Gentile, M.T.; Damato, A.; Cocozza, G.; Antenucci, G.; Mascio, G.; Bettarini, U.; Landolfi, A.; et al. Pressure-induced vascular oxidative stress is mediated through activation of integrin-linked kinase 1/ßPIX/Rac-1 pathway. Hypertension 2009, 54, 1028-1034. [CrossRef] [PubMed]

213. Magen, E.; Feldman, A.; Mishal, J.; Cohen, Z.; Schlezinger, M.; Ben Alon, D.; Linov, L. Potential link between C3a, C3b and endothelial progenitor cells in resistant hypertension. Am. J. Med. Sci. 2010, 339, 415-419. [CrossRef] [PubMed]

214. Hill, J.M.; Zalos, G.; Halcox, J.P.J.; Schenke, W.H.; Waclawiw, M.A.; Quyyumi, A.A.; Finkel, T. Circulating endothelial progenitor cells, vascular function, and cardiovascular risk. N. Engl. J. Med. 2003, 348, 593-600. [CrossRef]

215. Hage, F.G.; Oparil, S.; Xing, D.; Chen, Y.-F.; McCrory, M.A.; Szalai, A.J. C-reactive protein-mediated vascular injury requires complement. Arterioscler. Thromb. Vasc. Biol. 2010, 30, 1189-1195. [CrossRef] [PubMed]

216. Gao, Q.; Xie, H.; Zhan, H.; Li, J.; Liu, Y.; Huang, W. Prognostic values of long noncoding RNA GAS5 in various carcinomas: An updated systematic review and meta-analysis. Front. Physiol. 2017, 8, 814. [CrossRef] [PubMed]

217. Williams, G.T.; Mourtada-Maarabouni, M.; Farzaneh, F. A critical role for non-coding RNA GAS5 in growth arrest and rapamycin inhibition in human T-lymphocytes. Biochem. Soc. Trans. 2011, 39, 482-486. [CrossRef] [PubMed]

218. Wang, Y.N.Z.; Shan, K.; Yao, M.D.; Yao, J.; Wang, J.J.; Li, X.; Liu, B.; Zhang, Y.Y.; Ji, Y.; Jiang, Q.; et al. Long noncoding RNA-GAS5: A novel regulator of hypertension-induced vascular remodeling. Hypertension 2016, 68, 736-748. [CrossRef] [PubMed]

219. Zhang, X.; Yang, X.; Lin, Y.; Suo, M.; Gong, L.; Chen, J.; Hui, R. Anti-hypertensive effect of Lycium barbarum L. with down-regulated expression of renal endothelial lncRNA sONE in a rat model of salt-sensitive hypertension. Int. J. Clin. Exp. Pathol. 2015, 8, 6981-6987. [PubMed] 
220. Yang, Y.; Xi, P.; Xie, Y.; Zhao, C.; Xu, J.; Jiang, J. Notoginsenoside R1 reduces blood pressure in spontaneously hypertensive rats through a long non-coding RNA AK094457. Int. J. Clin. Exp. Pathol. 2015, 8, 2700-2709. [PubMed]

221. Hansson, G.K. Inflammation, atherosclerosis, and coronary artery disease. N. Engl. J. Med. 2005, 352, 1685-1695. [CrossRef] [PubMed]

222. Rafieian-Kopaei, M.; Setorki, M.; Doudi, M.; Baradaran, A.; Nasri, H. Atherosclerosis: Process, indicators, risk factors and new hopes. Int. J. Prev. Med. 2014, 5, 927-946. [PubMed]

223. Tabas, I.; García-Cardeña, G.; Owens, G.K. Recent insights into the cellular biology of atherosclerosis. J. Cell Biol. 2015, 209, 13-22. [CrossRef]

224. Park, K.-H.; Park, W.J. Endothelial dysfunction: Clinical implications in cardiovascular disease and therapeutic approaches. J. Korean Med. Sci. 2015, 30, 1213-1225. [CrossRef]

225. Hanson, M.; Gluckman, P. Endothelial dysfunction and cardiovascular disease: The role of predictive adaptive responses. Heart 2005, 91, 864-866. [CrossRef] [PubMed]

226. Pober, J.S.; Sessa, W.C. Evolving functions of endothelial cells in inflammation. Nat. Rev. Immunol. 2007, 7, 803-815. [CrossRef] [PubMed]

227. Aryal, B.; Suárez, Y. Non-coding RNA regulation of endothelial and macrophage functions during atherosclerosis. Vasc. Pharmacol. 2018, 114, 64-75. [CrossRef] [PubMed]

228. Li, M.; Qian, M.; Kyler, K.; Xu, J. Endothelial-Vascular Smooth Muscle Cells Interactions in Atherosclerosis. Front. Cardiovasc. Med. 2018, 5, 151. [CrossRef] [PubMed]

229. Li, H.; Zhu, H.; Ge, J. Long noncoding RNA: Recent updates in atherosclerosis. Int. J. Biol. Sci. 2016, 12, 898-910. [CrossRef] [PubMed]

230. Yao, X.; Yan, C.; Zhang, L.; Li, Y.; Wan, Q. IncRNA ENST00113 promotes proliferation, survival, and migration by activating PI3K/Akt/mTOR signaling pathway in atherosclerosis. Medicine 2018, 97, e0473. [CrossRef]

231. Zhang, Y.; Zheng, L.; Xu, B.M.; Tang, W.H.; Ye, Z.D.; Huang, C.; Ma, X.; Zhao, J.J.; Guo, F.X.; Kang, C.M.; et al. Lnc RNA-RP 11-714G18. 1 suppresses vascular cell migration via directly targeting LRP 2 BP. Immunol. Cell Biol. 2018, 96, 175-189. [CrossRef]

232. Zhou, T.; Chen, X. Long intergenic noncoding RNA p21 mediates oxidized LDL-induced apoptosis and expression of LOX-1 in human coronary artery endothelial cells. Mol. Med. Rep. 2017, 16, 8513-8519. [CrossRef]

233. Halimulati, M.; Duman, B.; Nijiat, J.; Aizezi, A. Long noncoding RNA TCONS_00024652 regulates vascular endothelial cell proliferation and angiogenesis via microRNA-21. Exp. Ther. Med. 2018, 16, 3309-3316. [CrossRef]

234. Liao, J.; He, Q.; Li, M.; Chen, Y.; Liu, Y.; Wang, J. lncRNA MIAT: Myocardial infarction associated and more. Gene 2016, 578, 158-161. [CrossRef]

235. Han, P.; Li, W.; Lin, C.-H.; Yang, J.; Shang, C.; Nuernberg, S.T.; Jin, K.K.; Xu, W.; Lin, C.-Y.; Lin, C.-J.; et al. A long noncoding RNA protects the heart from pathological hypertrophy. Nature 2014, 514, 102-106. [CrossRef] [PubMed]

236. Zhang, X.-Y.; Zhang, L.-X.; Tian, C.-J.; Tang, X.-Y.; Zhao, L.-M.; Guo, Y.-L.; Cheng, D.-J.; Chen, X.-L.; Ma, L.-J.; Chen, Z.-C. IncRNAs BCYRN1 promoted the proliferation and migration of rat airway smooth muscle cells in asthma via upregulating the expression of transient receptor potential 1. Am. J. Transl. Res. 2016, 8, 3409-3418. [PubMed]

(C) 2019 by the authors. Licensee MDPI, Basel, Switzerland. This article is an open access article distributed under the terms and conditions of the Creative Commons Attribution (CC BY) license (http://creativecommons.org/licenses/by/4.0/). 